\title{
Structure and evolution of an active resurgent dome evidenced by geophysical investigations: The Yenkahe dome-Yasur volcano system (Siwi caldera, Vanuatu)
}

\author{
E. Brothelande ${ }^{\mathrm{a}, \mathrm{b}, *}$, J.-F. Lénat $^{\mathrm{a}}$, M. Chaput ${ }^{\mathrm{c}, \mathrm{d}}$, L. Gailler ${ }^{\mathrm{a}}$, A. Finizola ${ }^{\mathrm{c}}$, S. Dumont ${ }^{\mathrm{a}, \mathrm{e}}$, A. Peltier ${ }^{\mathrm{f}}$, P. Bachèlery ${ }^{\mathrm{a}}$, \\ S. Barde-Cabusson ${ }^{g}$, S. Byrdina ${ }^{\text {h}}$, P. Menny ${ }^{\mathrm{a}}$, J. Colonge ${ }^{\mathrm{i}}$, G.A. Douillet ${ }^{\mathrm{j}}$, J. Letort ${ }^{\mathrm{i}}$, L. Letourneur ${ }^{\mathrm{k}}$, O. Merle ${ }^{\mathrm{a}}$, \\ F. Di Gangi ${ }^{1}$, D. Nakedau ${ }^{m}$, E. Garaebiti ${ }^{m}$
}

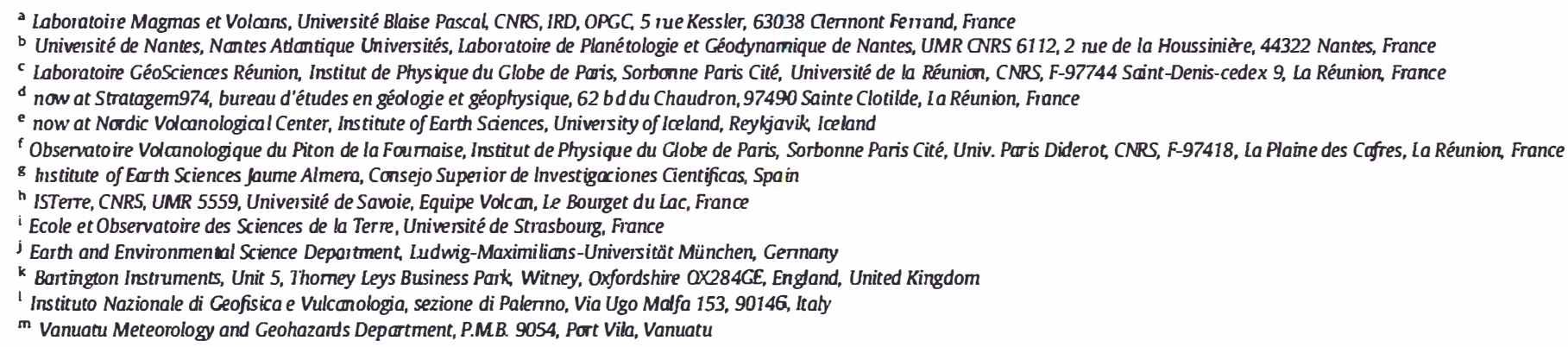

\section{A B S T R A C T}

In this contribution, we focus on one of the most active resurgences on Earth, that of the Yenkahe dome in the Siwi caldera (Tanna Island, Vanuatu), which is associated with the persistently active Yasur volcano. Gravity and magnetic surveys have been carried out over the past few years in the area, as well as electrical methods in-cluding electrical resistivity tomography (ERT), time domain electro-magnetics (IDEM) and self-potential (SP). These investigations were completed by thermometry, $\mathrm{CO}_{2}$ soil gas measurements, field observations and sam-pling This multi-method approach allows geological structures within the caldera to be identified, as well as as-sociated hydrothermal features. The global structure of the caldera is deduced fiom gravity data, which shows the caldera rim as a high density structure. Large lava fields, emplaced before and after the onset of resurgence, are evidenced by combined gravity, magnetic and resistivity signals. In the middle of the caldera, the Yenkahe dome apparently results from a combination of volcanic and tectonic events, showing that lava extrusion and re-surgence have been operating simultaneously or alternately during the Siwi caldera post-collapse history. There is a clear distinction between the western and eastern parts of the dome. The western part is older and records the giowth of an initial volcanic cone and the formation of a small caldera. This small caldera (paleo-Yasur calde-ra), partially filled with lava flows, is the present-day focus of volcanic activity and associated fluid circulation and alteration. The eastern part of the dome is presumably younger, and is characterized by intense, extensive hydro-thermal alteration and activity. Its northem part is covered by lava flow piles and exhibits a shallow hydrother-mal zone in ERT. The southern part has hydrothermal alteration and activity extending at least down to the base of the resuigent dome. This part of the dome is built up of low cohesion rock and is thus potentially prone to gravitational landslides. Lastly, while self-potential and temperature data suggest that widespread hydro-thermal circulation occurs throughout almost all of the caldera, and possibly beyond, the most active parts of this hydrothermal system are associated with the dome. The presence of this active hydrothermal system is the clearest indicator that these methods can provide of a potential shallow magmatic body un-derneath the dome.

\footnotetext{
- Corresponding author.

E-mail address: elodie_brothelande@yahoo.fr (E. Brothelande).
} 


\section{Introduction}

Resurgence is a common process corresponding to the postcollapse uplift of the caldera floor observed in many calderas (Smith and Bailey, 1968; Lipman, 1984; Newhall and Dzurisin, 1988). The phenomenon has been recognized in active or recent calderas as well as in old, sometimes deeply eroded ones (e.g. Yoshida, 1984; Fridrich et al., 1991; Du Bray and Pallister, 1999). Resurgence has traditionally been associated with large calderas of more than $10 \mathrm{~km}$ in diameter (Smith and Bailey, 1968; Steven and Lipman, 1976; Francis, 1983), though examples of smaller size exist (e.g. Cinque Denti, Panteleria; Mahood and Hildreth, 1986). Emplacement and dismantling processes of resurgent structures remain poorly constrained in most calderas. Different mechanisms have been identified as potential triggers for resurgence (Marsh, 1984 and references therein): relaxation of the crust following caldera collapse, emplacement of new intrusions, and pressurization of confined aquifers. Several approaches may be used to infer the dominant resurgence mechanisms at a given volcano. For old, eroded volcanoes, the geological approach is the most appropriate. For young and active volcanoes, various approaches contribute to our understanding of the mechanisms: analysis of the nature of young eruption products, geological and geophysical studies of the structures involved in (or created by) resurgence, and monitoring of geophysical and degassing signals.

We focus here on one of the most active resurgences on Earth, that of the Yenkahe dome in the Siwi caldera (Tanna Island, Vanuatu), which is associated with a permanently active volcano (Yasur). Apart from a few pioneering works (Carney and Macfarlane, 1979; Nairn et al., 1988; Chen et al., 1995), little is known about the post-collapse history of the caldera and the hazards associated with such a fast resurgence. Better constraining resurgence processes at Yenkahe involves unraveling the dome history (emplacement by intrusive and/or eruptive processes) as well as identifying main structures, fluid circulations and potential hydrothermal or magmatic sources of deformation. In this perspective, several recent studies have been led. In this contribution, we study the internal structure of the system and its hydrothermal activity coupling several geophysical methods. In terms of hazards, the geophysical data of this contribution allows identifying low-cohesion material, highlighting the probability of a future flank instability supported by external features. This study is complementary to two others led by our team, which allowed to better understand the global functioning and evolution of the Siwi-Yenkahe-Yasur complex. The first one concerns the structural aspect in terms of external tectonic features using the results of a newly-computed high-resolution photogrammetric digital surface model (DSM; Brothelande et al., 2016a). The second one uses internal and external features to constrain deformation models of magmatic intrusions in the upper crust (Brothelande et al., 2016b).

For this study, three geophysical campaigns have been carried out within the Siwi caldera, in 2004, 2008 and 2012, including gravimetry, magnetics, time-domain electromagnetics (TDEM), electrical resistivity tomography (ERT), self-potential (SP), ground temperature and $\mathrm{CO}_{2}$ soil concentration measurements. Rock sampling and thermal infrared data were used to complete this data set. Given the large amount of data, the results of each method are first described separately, before proposing a combined interpretation in terms of the inner structure of the Siwi-Yenkahe-Yasur complex and the associated fluid circulation pattern. The implications of these geophysical results are then discussed in terms of dome history and evolution.

\section{General context}

\subsection{The Vanuatu arc and Tanna Island}

Volcanism of the Vanuatu oceanic arc (formerly known as the New Hebrides) results from the subduction of the Indo-Australian plate beneath the Pacific plate (Pelletier et al., 1998; Calmant et al., 2003). Tanna Island, located on the southern segment of the arc, is a large structure, $60-80 \mathrm{~km}$ wide on the sea floor, and about $2 \mathrm{~km}$ high (Robin et al., 1994). The geology of Tanna Island (40 × 16 km; Fig. 1a), described in a few pioneering works (Carney and Macfarlane, 1979; Robin et al., 1994; Chen et al., 1995; Neef et al., 2003; Allen, 2004), is not known in detail. The island was built by volcanic activity and coral reef growth. Three volcanic complexes were recognized by Carney and Macfarlane (1979): the Upper Pliocene to Pleistocene Green Hill to the north, the Pleistocene Tukosmeru volcano to the south and the Siwi Group Volcanic Centre (Upper Pleistocene to present) to the east. In addition, Robin et al. (1994) proposed the existence of a Pliocene-Pleistocene volcano, named Eastern Tanna volcano; the center of this volcano would be located offshore of the north-east coast of the northern part of the island.

\subsection{Structure and activity of the Siwi caldera}

The Siwi caldera is located at the base of a huge amphitheater-like depression on the eastern flank of the Tukosmeru volcano (Fig. 1a), and is a more or less rectangular structure $(9 \times 4 \mathrm{~km}$ for the inland part; Fig. 1b). The caldera is bounded by faults a few tens of meters to nearly $100-\mathrm{m}$ high, and its eastern extent is unknown as the caldera is open to the sea. The Siwi caldera formation has been associated with an ignimbrite eruption of rather small-volume (1-2 $\mathrm{km}^{3}$; Allen, 2004; Nairn et al., 1988; Robin et al., 1994). The caldera collapse is still undated, but the freshness of the deposits and the morphology suggest a relatively young age to some authors (less than 20,000 years for Nairn et al., 1988). The Yenkahe dome, $\sim 5 \mathrm{~km}$ long by $\sim 3 \mathrm{~km}$ wide and $\sim 200-300 \mathrm{~m}$ high, in the middle of the Siwi caldera, is elongated in the same direction as the caldera (Fig. 1b). Its origin is attributed to a resurgent doming process, well illustrated by the presence of emerged corals and waterlain tuffs at its surface (Carney and Macfarlane, 1979; Nairn et al., 1988; Chen et al., 1995; Neef et al., 2003). Chen et al. (1995) performed ${ }^{230} \mathrm{Th} /{ }^{234} \mathrm{U}$ dating on coral samples from terraces on the eastern part of the Yenkahe dome, at mean altitudes of $155 \mathrm{~m}$ and $15 \mathrm{~m}$ above sea level. Respective ages of $\mathrm{AD} 1002 \pm 10$ and $\mathrm{AD}$ $1868 \pm 4$ imply a mean uplift of $156 \mathrm{~mm} /$ year for the eastern part of the Yenkahe dome in recent times. Resurgence has been attributed to magma intrusion at depth (Carney and Macfarlane, 1979; Nairn et al., 1988; Chen et al., 1995; Metrich et al., 2011), and the study of Chen et al. (1995) suggests that resurgence occurred mostly during discrete uplift events. This is well illustrated by the co-seismic uplift events of 6 and $4 \mathrm{~m}$ in 1878 (Chen et al., 1995 and references therein). Hydrothermally altered and warm ground spots are frequent at the surface of the Yenkahe dome (Peltier et al., 2012).

The Yenkahe dome is associated with two strombolian cones. The Ombus cone, located at the southern foot of the dome (Fig. 1b), is extinct and now heavily covered by vegetation. The Yasur cone is the present-day focus of volcanic activity, located at the north-western edge of the Yenkahe dome (Fig. 1b). The three presently active vents inside the Yasur crater have frequent (every few minutes) strombolian explosions that expel ashes, scoriae, Pele's hair and centimeter-tometer-sized bombs of basaltic-trachyandesitic composition (Metrich et al., 2011). The cone is built up of the accumulation of these products, and is located on a former volcanic center, of which the remnants of a pyroclastite cone and a caldera-like structure can be observed (Carney and Macfarlane, 1979; Merle et al., 2013). Nairn et al. (1988) have proposed, on the base of the analysis and dating of two ash sequences to the northwest of Yasur that the paleo-Yasur could have been active from 1,400 to 800 years ago, before the young Yasur started its activity. More recently, Firth et al. (2014), by analyzing two other ash sequences, proposed that the Strombolian-style activity at Yasur has persisted in its current form for the last $630-850$ years and was preceded by $\sim 600$ years of higher-magnitude, lower-frequency eruptions during which less evolved compositions were erupted. 

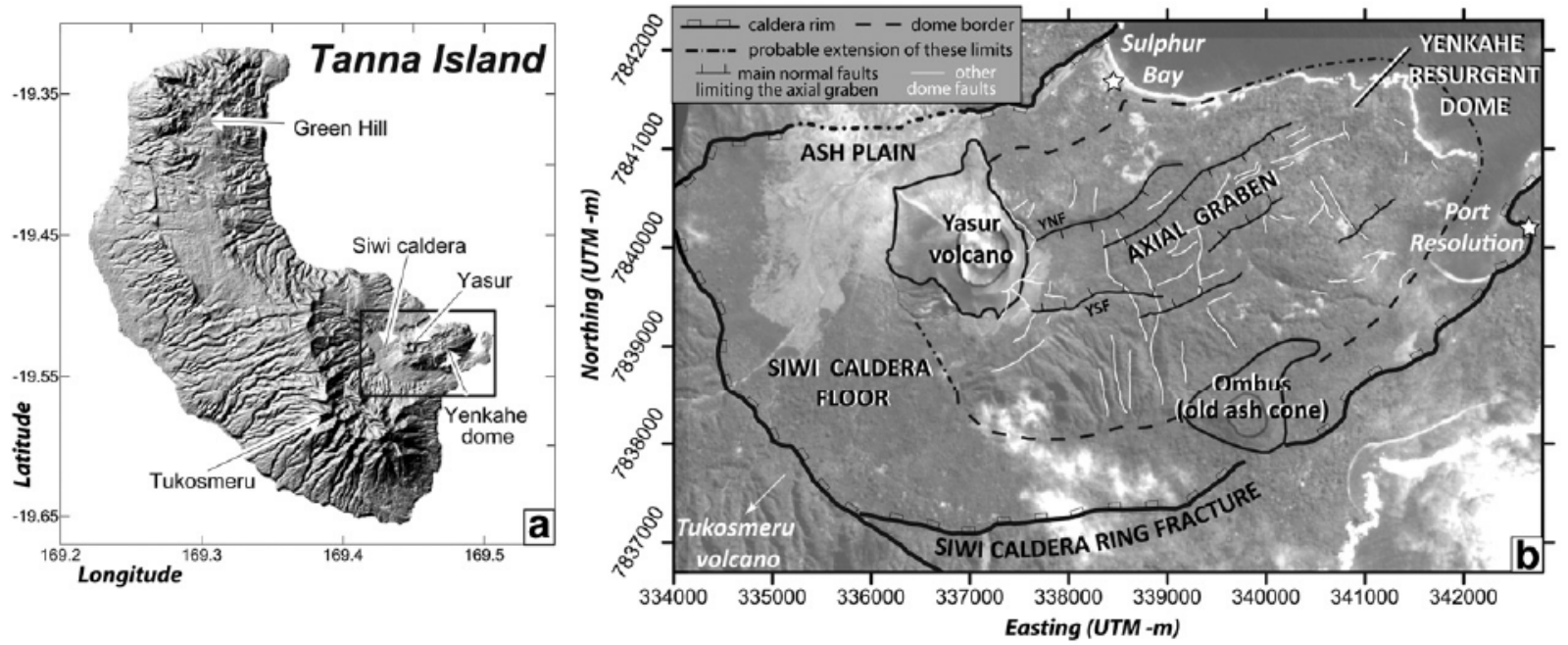

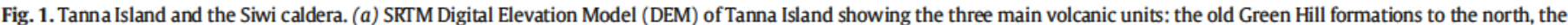

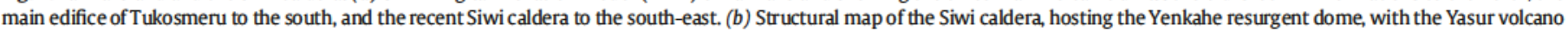

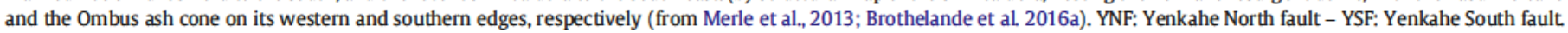
Stars indicate main localities. WGS84 coordinates.

The main stages of the Yenkahe dome tectonic evolution have been studied by Merle et al. (2013). They suggest the early formation of a resurgent dome in the west. Then, following or accompanying the collapse of the paleo-Yasur small caldera, the doming moved, uplifting immerged parts now observed on the easternmost side of the dome. They attribute the eastward migration of resurgence to a lateral magma intrusion. The eastern part of the dome has been very active in the recent period, as shown by the 1878 episodes of uplift and the widespread hydrothermal activity at the surface.

\subsection{Previous structural geophysical studies}

Relatively few geophysical works have been published on the SiwiYenkahe-Yasur complex. Reconnaissance work (seismic acquisition) was done by Blot and Tazieff (1961). Nabyl et al. (1997) studied the signals associated with the Yasur explosive activity. More recently, Perrier et al. (2012) used small aperture array measurements of seismic noise at seven sites around Yasur to estimate the $P$ and $S$ wave velocities at shallow levels (about $200 \mathrm{~m}$ ). They principally showed lower velocities inside the Siwi caldera than at its periphery. Finally, Battaglia et al. (2012) showed that a magnitude 7.3 earthquake occurring $80 \mathrm{~km}$ away from Yasur caused a sudden seismic velocity drop below the Yasur volcano, followed by a slow partial recovery.

Malahoff (1970) conducted reconnaissance gravity and aeromagnetic surveys on the scale of the entire arc. Unfortunately, the data density of these surveys is too low to be useful for our study. Lardy and Tabbagh (1999) showed the presence of an abnormally high heat flux by monitoring the ground temperature along vertical profiles near the northern rim of the Siwi caldera. Peltier et al. (2012) carried out a high resolution survey of the subsurface temperature of a large part of the Yasur cone and its foot. They evidenced thermal anomalies associated with faults and crater rims.

The other published studies were dedicated to the flux and nature of the gases emitted by Yasur (Oppenheimer et al., 2006; Bani and Lardy, 2007; Bani et al., 2013) and to the acoustic signal of its explosions (Zielinski, 2012; Kremers et al., 2013; Marchetti et al., 2013). However, it is worth noting that petrology and geochemistry works by Metrich et al. (2011) and Gauthier (2001) provide some constraints on the depth of magma reservoirs, the volume of degassed and non-erupted magma and the pressure and temperature of the hydrothermal system. On the basis of the gas flux, Metrich et al. (2011) estimated the volume of degassed magma for the present activity at $10^{7} \mathrm{~m}^{3} \mathrm{a}^{-1}$. At most, only $5 \%$ of the basaltic-trachyandesite magma is erupted. The remaining $95 \%$ must accumulate at depth. For a more or less constant activity, similar to the present one, over the last millennium, the degassed volume accumulated beneath the Siwi caldera would be ten times larger than the volume of the resurgence. Gauthier (2001) establishes that the fumaroles and hot waters of the Siwi-Yenkahe complex have a clear magmatic component, indicating the degassing of a magmatic reservoir or intrusion complex beneath the Yenkahe resurgent dome. Thermodynamic models indicate a temperature of $200-250^{\circ}$ for the geothermal reservoir and a pressure corresponding to a depth of about $150 \mathrm{~m}$.

\section{Methods}

Over the last ten years, several near-surface geophysical investigation methods have been carried out within the Siwi caldera. A reconnaissance self-potential (SP) survey was performed in 2004, followed by a pluridisciplinary survey in 2008 including gravimetry, timedomain electromagnetics (TDEM), electrical resistivity tomography (ERT), self-potential, ground temperature and $\mathrm{CO}_{2}$ soil concentration measurements. This data set was completed in 2012 by a magnetic survey.

Three methods have been carried out across the entire caldera to characterize its general structure in terms of rock density (gravity), magnetization (magnetics), and hydrothermal activity (SP). Although the data coverage is heterogeneous, due to the difficulty of accessing some areas and the limited time of the campaign, the surveys provide valuable information for many key areas in terms of lithology and state of hydrothermal alteration or current circulation. The gravity land survey was performed with a Scintrex CG5 gravimeter and comprises 272 stations (Fig. 2a). Gravity station coordinates were determined using a differential GPS technique with a decimetric precision. Data was then processed using standard procedures (tidal variations and instrumental drift, free air gradient, Bouguer slab and terrain corrections). The uncertainty on gravity measurements ranges from 0.007 to $0.75 \mathrm{mGal}$ with a mean value of $0.25 \mathrm{mGal}$, and $0.012 \mathrm{~m}$ for elevation measurements. More details about data processing can be found in Appendix A of the Supplementary Online Material. The magnetic ground survey (Fig. 2b) was made using a portable magnetometer (GEM GSM-19) using the walking mode with GPS simultaneous positioning (GEM-Systems-Inc, 2008). No corrections were made for the diurnal 

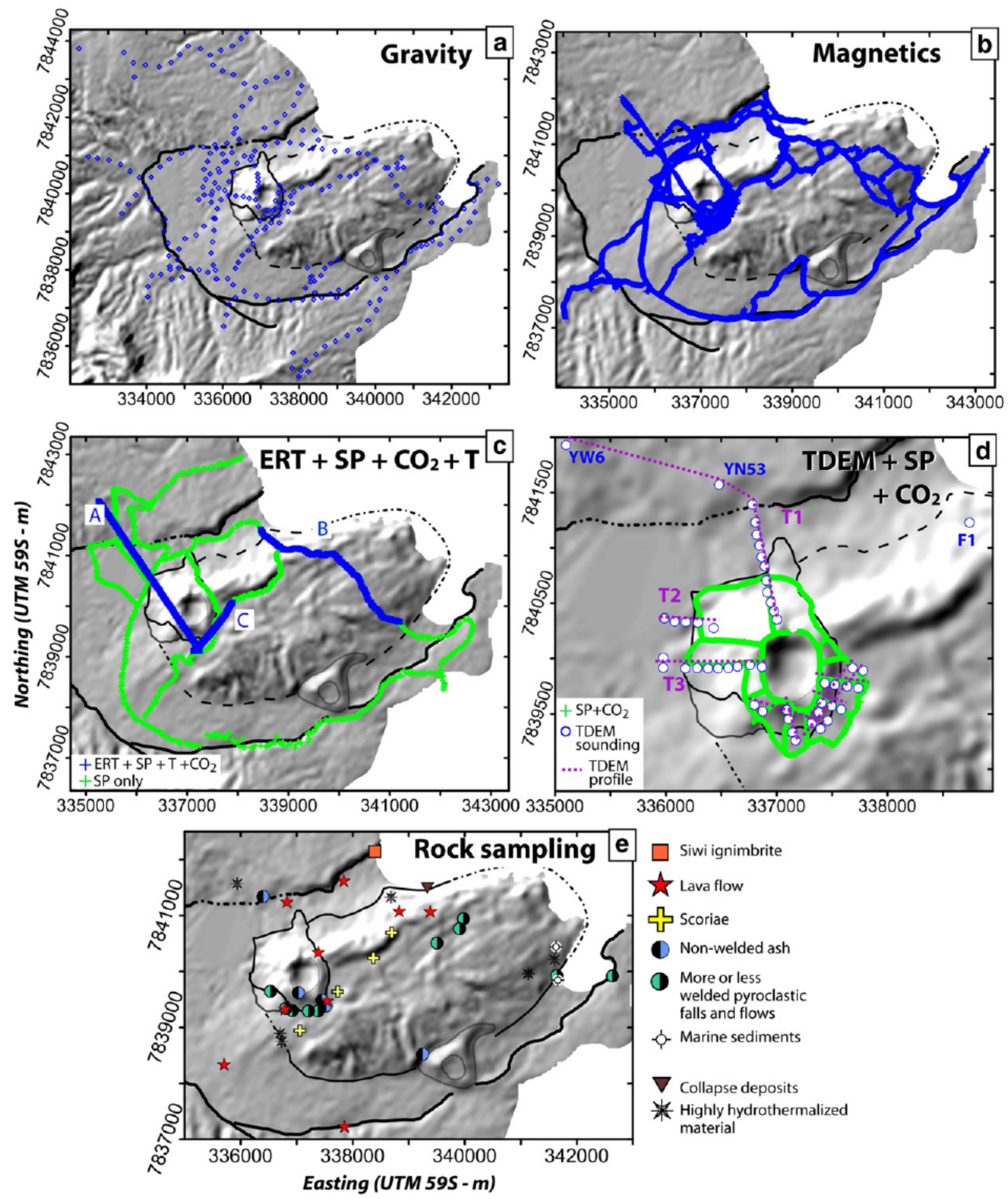

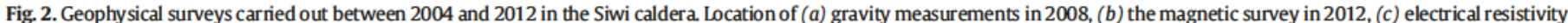

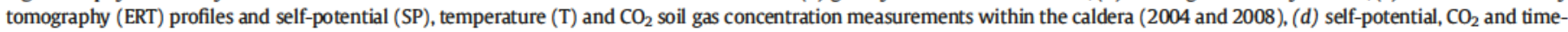
domain electromagnetic measurements (TDEM) on the Yasur cone in 2008, and (e) rock samples collected in the field in 2012. UTM (m) WGS84 coordinates.

variation owing to the very large amplitude of the anomalies. The IGRF field at the time of acquisition was subtracted from the observed magnetic field values to obtain the magnetic anomaly. Details on further processing, such as data filtering and upward continuation, are documented in Appendix B of the Supplementary Online Material. The self-potential method, measuring quasi-static natural electrical potential differences at the ground surface, was performed with a pair of non-polarizing $\mathrm{Cu} / \mathrm{CuSO}_{4}$ electrodes, a high-impedance voltmeter of
$0.1 \mathrm{mV}$ sensitivity and an insulated $300 \mathrm{~m}$-long copper cable. An electrode spacing of $50 \mathrm{~m}$ was used for the caldera-scale survey (Fig. 2c). After control and correction of the electrode offset, all measurements were reduced to a common reference potential ( $0 \mathrm{mV}$ on the seashore) and corrected for closure errors. In volcanic areas, positive SP anomalies generally reflect the upward flow of hydrothermal fluids. Positive peaks can be hidden by the SP/elevation hydrogeological gradient that may be subtracted from the signal when identified ("elevation-corrected 
signal"). Details on the SP method are given in Appendix C of the Supplementary Online Material.

Other electrical methods such as TDEM and ERT were performed in order to image the resistivity structure under specific zones. Resistant bodies (a few thousand ohm $\mathrm{m}$ ) are typical for dry rock, whereas very low resistivity values (a few ohm $\mathrm{m}$ to a few tens of ohm $\mathrm{m}$ ) reflect the effect of hydrothermal fluids or alteration. ERT measurements were performed with a multi-electrode ABEM system (Terrameter SAS4000) and a line of 64 electrodes, using the so-called roll-along procedure when required (Loke, 2014). The acquisition followed a Wenner protocol, providing a good signal-to-noise ratio. Three profiles were carried out (Fig. 2c) with an electrode spacing of $40 \mathrm{~m}$ for profiles A $(3640 \mathrm{~m})$ and B (3800 m), and $20 \mathrm{~m}$ for profile C (1260 m). The maximum depth of investigation is around $400 \mathrm{~m}$ and $200 \mathrm{~m}$ for the measurements with $40-\mathrm{m}$ and $20-\mathrm{m}$ electrode spacings, respectively. Profiles A and C, in the Yasur area, follow a straight path, whereas profile $B$, constrained by existing pathways across the dense tropical forest in the eastern part of the resurgent dome, follows a crooked line. Electrode positions were obtained by GPS measurements, and elevations were deduced from the SRTM Digital Elevation Model ( $90 \mathrm{~m}$ resolution, $\sim 8 \mathrm{~m}$ accuracy according to Brothelande et al., 2016a). Filters were applied in order to reduce the noise in the profiles, and apparent resistivity data including topography information were then inverted using RES2DINV software (Loke and Barker, 1996). Details on the ERT method and filtering procedures are given in Appendix D of the Supplementary Online Material and complementary information may be found in Brothelande et al. (2014). Forty-five TDEM soundings were made using a TEM-Fast 48 equipment (from AEMR soundings) to cover the Yasur cone and the floor of the Siwi caldera to the north and northwest of the Yasur (Fig. 2d). Two additional ones are located outside the caldera to the north and north-east (YN53 and YW6, respectively) and one is on a hydrothermal area to the east (F1). Coincident transmitter and receiver $100-\mathrm{m}$ square loops and $1 \mathrm{~A}$ current were used. Because most soundings are distributed along profiles, it was possible to construct 2D sections by interpolation between 1D models. Details about the TDEM method and data processing are given in Appendix $E$ of the Supplementary Online Material. In order to characterize the current fluid circulations along ERT sections and in the Yasur area, SP, ground temperature and $\mathrm{CO}_{2}$ diffuse degassing measurements (Fig. 2c; Appendixes C, F of Supplementary Online Material) were performed with a $20-\mathrm{m}$ and $10-\mathrm{m}$ spacing, respectively.

Finally, rock samples were collected in 2008 and 2012 for geological studies and for measuring physical properties in order to constrain the geophysical models (Fig. 2e). Global temperature coverage of the dome was also obtained from Aster data acquired in 2005 to complete this data set (the processing is detailed in Appendix F of the Supplementary Online Material). In situ brightness temperature measurements were performed with an infrared thermometer (Cyclops 300AF) to estimate the amplitude of local anomalies in identified hydrothermal areas.

\section{Results and interpretations}

\subsection{Density structure}

\subsubsection{Qualitative interpretation of Bouguer anomalies}

Calderas resulting from explosive activity are generally associated with negative gravity anomalies, because the material filling the caldera depression, mostly pyroclastic, is usually less dense than the host rocks (e.g. Kane et al., 1976; Rapolla et al., 1989; Campos-Enriquez and Arredondo-Fragoso, 1992). The residual Bouguer anomaly map of the Siwi caldera fits with this common scheme (Fig. 3a; Fig. A.3 of the Supplementary Online Material). Positive anomalies coincide with the caldera ring fault (with negative gradients towards the inside) except where the negative anomaly associated with the Ombus cone overlaps the caldera boundary.
Inside the caldera, shorter wavelength Bouguer anomalies are present. The most prominent is the negative anomaly of the Yasur cone (Yon Fig. 3a), indicating its overall low density. The center of the anomaly is located to the NW of the crater, where the cone is expected to be thicker because of the altitude difference between the top and the base of the resurgent dome. The low density of the cone can be explained by the nature of its products (mostly unwelded cinders, scoriae and bombs). The same gravity pattern is observed for the Ombus cone ( 0 on Fig. 3a), although it is not well covered by data.

The second main gravity feature in the caldera is the negative anomaly occupying the eastern part of the Yenkahe resurgent dome ( $\mathrm{H}$ on Fig. 3a), though the data distribution does not allow us to establish the northern and south-western extents of this anomaly. In this area, low density rocks are expected for two reasons. Firstly, at the surface we mostly observe uplifted corals and waterlain tuffs, all having a relatively low density. Secondly, this is also the most hydrothermalized area at the surface and at depth (see Section " 4.3 Resistivity structure" below) and this alteration is also known to lower the density of rocks.

Between anomalies $\mathrm{Y}$ and $\mathrm{H}$, several individual anomalies are identified (Fig. 3a). The positive anomaly F partly overlaps with the base of the Yasur cone. It seems to coincide well with the lava flow infilling of the small paleo-Yasur caldera inferred from the magnetic and resistivity data described below (Sections 4.2,4.3). This suggests that this infilling extends below the present Yasur cone, whose gravity effect would hide the postulated continuation of anomaly $\mathrm{F}$ to the NE. The negative anomaly $\mathrm{N}$ coincides with the location of two major normal faults transverse to the elongation of the dome apical graben (Nairn et al., 1988; Merle et al., 2013). Scoriae are also observed in this area (Fig. 2e). The short wavelength of this anomaly implies a shallow source, but it is not possible to establish if the low density is related to the faults or to a scoriaceaous construction. Positive anomalies I and L form a more or less continuous unit. Determining the nature of their sources would be speculative here, but we see in Section 4.2 (magnetic data) that this area is covered by lava flows. I and L may be created by a shallow lava flow field, the density of lava flows being higher than that of the pyroclastites. In addition, a negative anomaly (W) is observed on the western foot of the resurgent dome. This zone corresponds to a taluslike morphology at the base of the resurgent dome. Although this landform is now covered by lava flows, it may have been created by a landslide at the western border of the resurgent dome. The presence of mass wasting breccias could thus explain the negative anomaly $\mathrm{W}$.

\subsubsection{Quantitative interpretation: modeling of the main anomalies}

Considering the data distribution, we have chosen to calculate $23 / 4 \mathrm{D}$ models along a profile oriented WSW-ENE (Fig. 3a). This profile crosses nearly all the structures identified in the geological and geophysical observations. In order to better constrain density contrasts in the models, the density of various types of rock samples has been measured (see Table A.1 and Fig. A.2 in Appendix A of the Supplementary Online Material). However, it should be stressed, on the one hand, that the density measurements of 25 or so superficial rock samples cannot encompass the whole diversity of the area, and, on the other hand, that the density of a sample may not be representative of the macroscopic density of a geological formation of the same rock.

The main structures that have to be considered in a model are governed by the geological and geophysical observations. In this case, they are: (1) the host rocks of the caldera (substratum), (2) the caldera filling of pyroclastites, (3) the pyroclastic cones, (4) the sediments (corals and waterlain tuffs), (5) the hydrothermalized rocks, and (6) the lava flows. In addition, an intrusive system (7) should also be considered to account for resurgence. The density, depth and thickness of these layers are parameters that have to be adjusted in the models. Consequently, as is well known for the modeling of gravity anomalies, the observed data can be explained by a large range of models, unless very strict constraints can be applied to the parameters. Here, we cannot fix stringent constraints for the density and the depth and/or thickness 

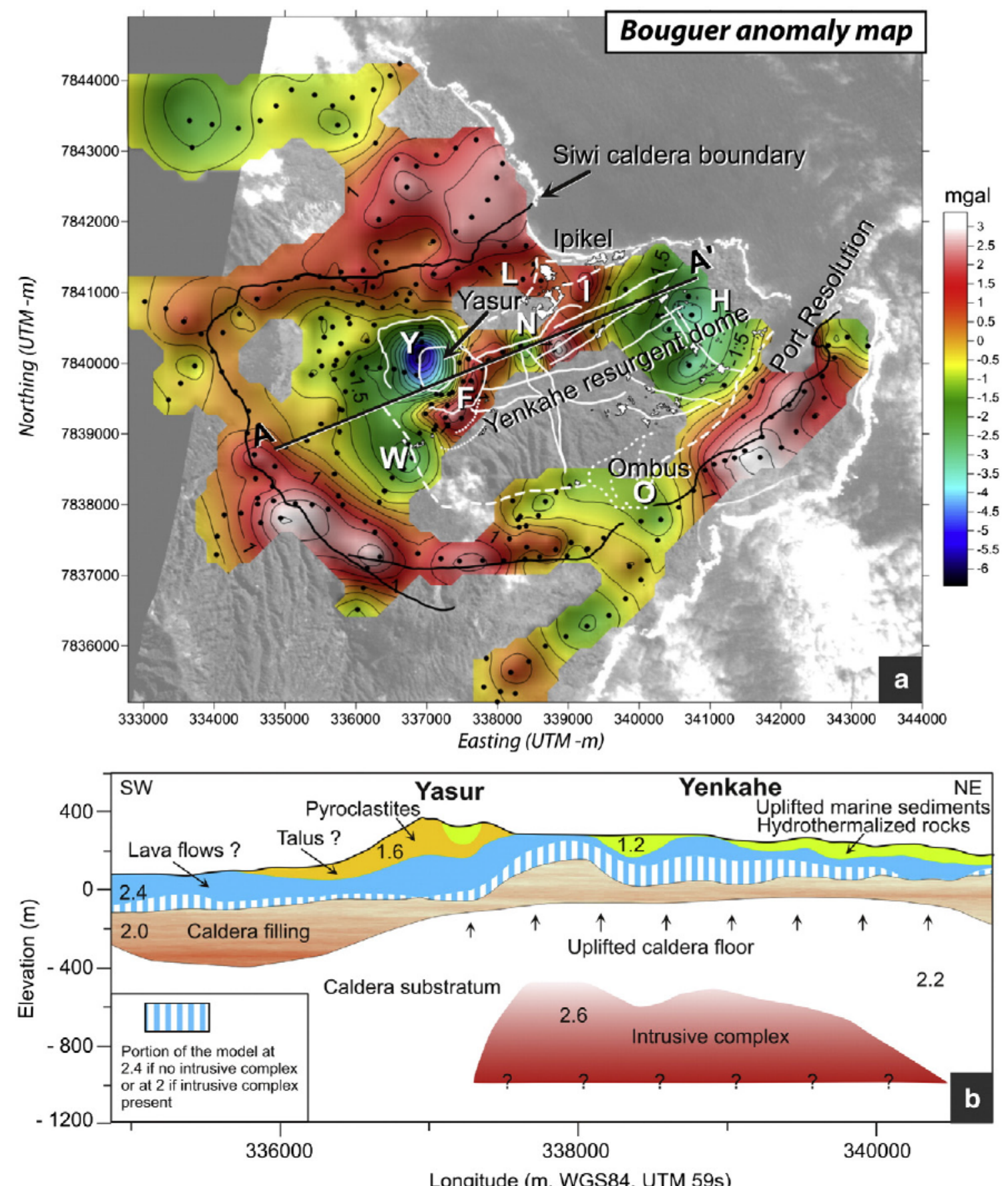

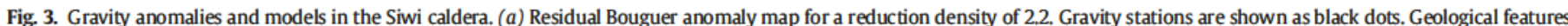

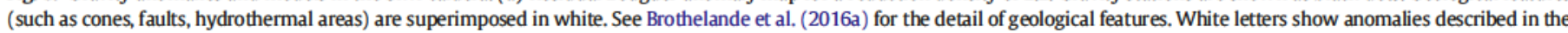

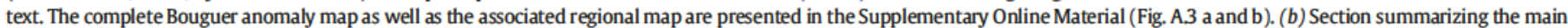

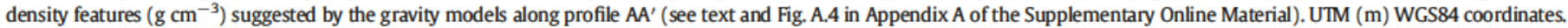

of the different structures. Therefore the models only represent plausible solutions for the density distribution. The crucial question in the study of resurgent domes is whether the source of doming, probably magmatic, can be constrained by geophysical data. We have thus chosen to investigate two endmember models: one with a denser intrusive system at depth (the 1-km depth results from deformation models of Brothelande and Merle, 2015, and Brothelande et al., 2016b) and one without such a system. The two models, which both fit the data equally well, are presented in Fig. A.4 in Appendix A of the Supplementary
Online Material. In Fig. 3b, we show a section that summarizes the main features deduced from the gravity models. Varying the density contrasts changes the thickness of the layers but does not significantly alter the general gravity structure. The models account for the presence of well identified low density structures such as the Yasur cone and the sediments and/or hydrothermally altered rocks to the east. Anomaly $\mathrm{N}$ (Fig. 3a) requires the presence of shallow low density rocks. At depth, the presence or the absence of a dense intrusive complex can be compensated in the data by the thickness of the shallow 2.4-dense bodies 
that can be tentatively attributed to sequences of massive lava flows. As observed for other resurgent calderas (e.g. Toba, Masturyono et al., 2001), the presence of a dense intrusive complex beneath the resurgent dome cannot be established unambiguously, but remains compatible with gravity data (for a density of 2.6).

\subsection{Magnetic structure}

\subsubsection{Surface and shallow magnetic sources}

A magnetic ground survey (Fig. 2b; Fig B.1 in Appendix B of the Supplementary Online Material) was carried out in June-July 2012 to investigate rock magnetization within the caldera. On the one hand, massive mafic volcanic rocks (lava flows, dikes), such as the ones produced by the volcanoes on Tanna, are highly magnetized because of their high oxide contents compared to most types of rocks. Considering the surface of lava flows is always irregular at scales of less than meters or decameters, magnetic measurements collected at low elevation above a mafic lava flow will exhibit typical large amplitude variations at these scales. On the other hand, low surface magnetizations can also be expected in the volcanological context of Tanna, for several reasons. Firstly, pyroclastites have a much lower magnetization than their massive counterparts. Secondly, hydrothermal alteration considerably lowers the magnetization of all types of rocks (e.g. Palmason, 1975; Hochstein and Soengkono, 1997; Bouligand et al., 2014), which may be observed in Figs. 4a and B.2 (Appendix B of the Supplementary Online Material). Finally, some poorly magnetized non-volcanogenic sedimentary rocks (coral, water-lain deposits) are present in the study area.

The presence of shallow, massive, unaltered volcanic rocks can be easily detected on the magnetic ground survey by the presence of high frequency spatial variations in the measured magnetic field. For this purpose, we have applied a high-pass filtering to the total magnetic anomaly to isolate wavelengths below $50 \mathrm{~m}$. The absolute amplitude of the resulting signal is shown on Fig. 4a and b. Three main types of zones can be distinguished: (1) zones dominated by high amplitude signal (black to blue), (2) zones more or less devoid of high frequency signal (yellow to red), and (3) intermediate zones (mixed signals).

Type (1) can be unambiguously identified as shallow lava flows. Two large lava flow fields are thus recognized, to the north and south of Yasur (Fig. 4b). The southern one corresponds to a well visible deltalike topographic feature originating from the southern foot of the present Yasur cone. Lava flows outcrop at the southern foot of the Yasur cone and in the caldera moat. For the northern lava field, the lava flows are covered by cinders but can be observed in the bed of the river near the northern rim of the caldera and at some locations on the resurgent dome (Figs. 2e, 4b). Because of the lack of magnetic data in the middle part of the postulated field, it is not possible to establish whether or not the field is continuous. However, in the north-eastern part of this field, magnetic profiles show a clear continuity of the high frequency signal from the caldera moat to the top of the resurgent dome.

As the northern flow field includes a part of the northern resurgent dome and is affected by graben faults (related to doming), it has probably been uplifted since its formation (i.e. the bottom of the caldera was more or less flat at the time of the emplacement of the lava flow field and the resurgence started later). An alternative explanation is to consider that the lava flows on the resurgent dome have been emitted from vents located on the dome itself. However no such vents have been yet documented or recognized. Given their shape and location, northern and southern lava flow fields may have originated from the Yasur area (Fig. 4b). However, both fields may correspond to multiple emplacement events, with recent lava flows emitted from the Yasur volcano.

Type (2) magnetic pattern is found in different areas. The highly hydrothermalized area at the northern foot of the resurgent dome
(Ipikel Beach on Fig. 4a) belongs to this type. The contrast with type (1) can be illustrated on the profile shown in Fig. 4a, where we observe a sharp break between the two types. The contrast might be partially due to a lithology contrast (no lava flow outcrops observed on type (2) area of the dome, only ashes and uplifted water-lain layers and corals), but obliteration of the rocks' magnetization by hydrothermal alteration (Hochstein and Soengkono, 1997; Bouligand et al., 2014) is very likely the main cause of the contrast. This is supported by detailed examination of a type (1) zone, where magnetic profiles cross active hydrothermal zones at the surface. On Fig. B.2 (Appendix B of the Supplementary Online Material), we can easily observe that type (1) is locally interrupted by type (2) patterns over the hydrothermal areas. The same reasoning applies to the type (2) zones observed over the Ipikel beach hydrothermal area (see Fig. 4a), and in places on the Yasur cone area (Fig. 4b) where surface hydrothermal activity is observed (Peltier et al., 2012).

Other areas where the type (2) magnetic pattern is observed are the caldera moat, apart from on the lava flow fields, and the exterior of the caldera to the south-west. In these zones, no hydrothermal alteration is required to explain the magnetic pattern if the underlying rocks are predominantly pyroclastites. A remarkable illustration is the hummocky deposits of the 1975 Yasur cone landslide (Fig. 4b). Here about ten meters of rocks from the cone (pyroclastites) rest on the postulated lava flow field, and this is enough to interrupt the type (1) pattern locally. Finally, two type (3) (i.e. intermediate pattern) zones are observed. The first one is located beyond the caldera, to the south-east. The magnetic pattern suggests the presence of both pyroclastites and lava flows in this area. The second one is the flanks and foot of the Yasur cone on the resurgent dome (Fig. 5). This area is complex and requires a more detailed analysis that is made possible by the good magnetic coverage of the southern and eastern parts of this area. The presence of lava flows, pyroclastites and hydrothermal areas results in a composite magnetic pattern. An upward continuation of the survey to a constant elevation of $380 \mathrm{~m}$ ( $\sim$ maximum elevation in the area) provides a magnetic map free from the high frequency signal linked to surface heterogeneities (Fig. B.3 in Appendix B of the Supplementary Online Material). 2D models along two parallel profiles oriented SE-NW allow us to constrain the structure of the zone, the southern one being shown on Fig. B.3. The model clearly indicates that, below the present Yasur cone, highly magnetized layers are present (magnetization contrast: 5-15 $\mathrm{A} \mathrm{m}^{-1}$ ). The most straightforward interpretation of this magnetized body would be an accumulation of lava flows. We note that this interpretation agrees well with that of the ERT and TDEM data described below (Section 4.3.2). Within the framework of the geological observations that suggest the existence of a more or less circular collapse of the area underlying the present cone (Carney and Macfarlane, 1979; Nairn et al., 1988; Brothelande et al., 2016a), we infer that the highly magnetized body may correspond to the infilling of this depression by effusive activity (Fig. 5), although the magnetic coverage does not extend far enough to the east and south of the area to establish this interpretation unambiguously. On Fig. 5, we also note two types of features. Firstly, the positive anomaly related to the inferred lava flow infilling of the collapse is clearly perturbed by the faults in the extension of the Yenkahe axial graben to the east. Vertical displacements along these faults and associated hydrothermal circulation (Peltier et al., 2012) postdate the infilling of the collapse. Secondly, a distinctive high frequency pattern is observed for the zone to the south of the cone, above what seems to be the youngest lava flow of the area (Brothelande et al., 2016a). The shape of the magnetic pattern suggests that the lava flow was emitted from a vent located on the south flank of the present cone, where a partially buried notch is clearly observed in the topography. This strongly suggests that the lava flow emission postdates the beginning of the construction of the present Yasur cone, thus indicating the relative recentness of the lava flow (possibly from 1878 according to Aubert de la Rüe, 1960). To the west, the lava flow moved into the southern lava flow field described above. 

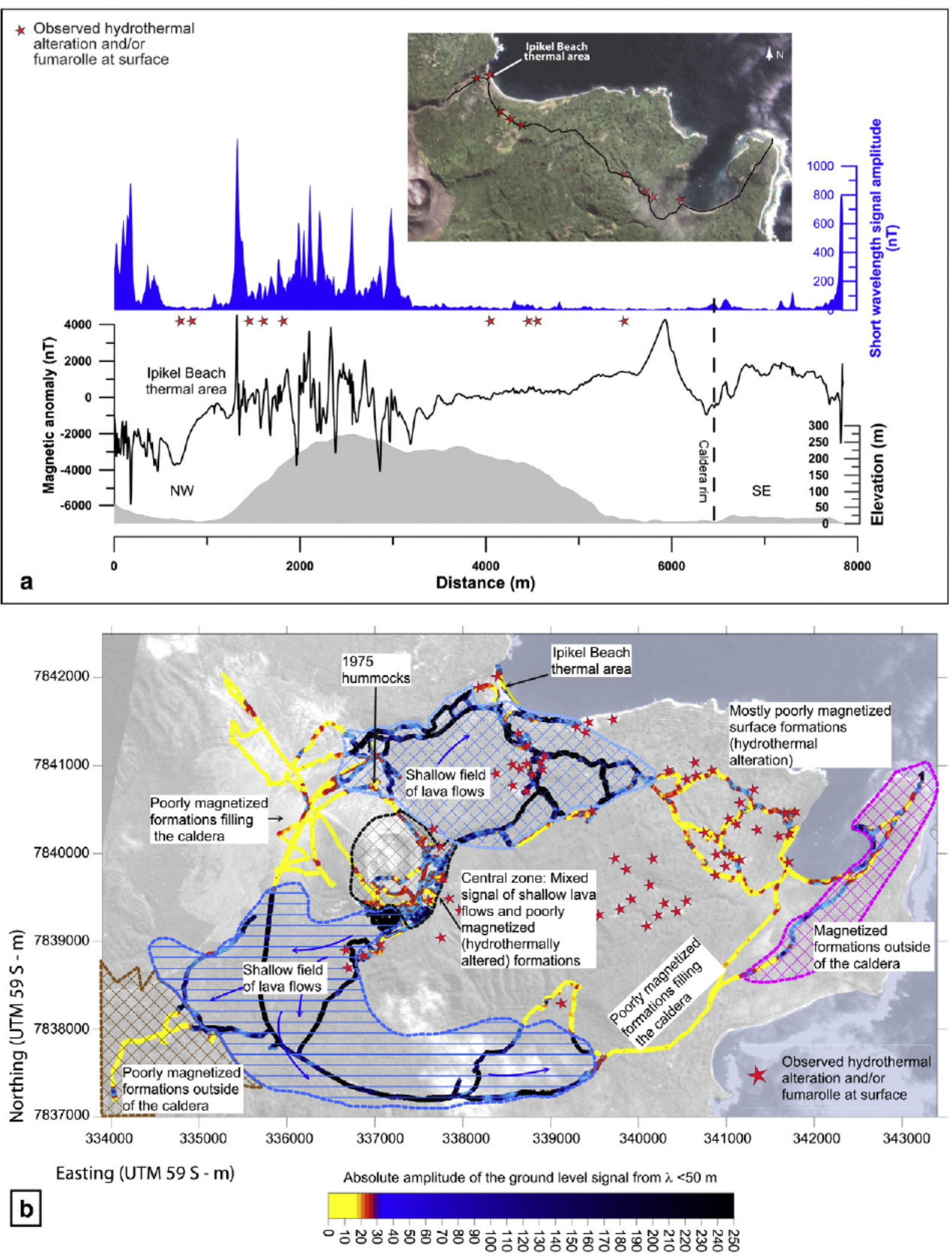

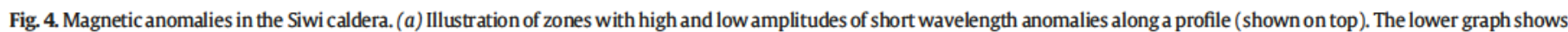

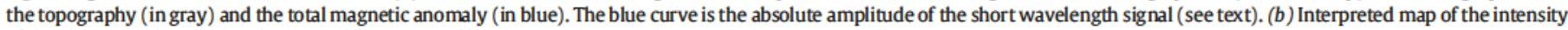
of the short wavelength signal extracted from ground level magnetic anomaly. UTM (m) WGS84 coordinates.

\subsubsection{Deeper magnetic sources}

The survey is not tailored to study the deep structure of the area, because long wavelength anomalies expected for deeper magnetic contrasts are not well constrained by the limited coverage of magnetic data. However, in two areas, the magnetic survey provides information about non-outcropping rocks. 


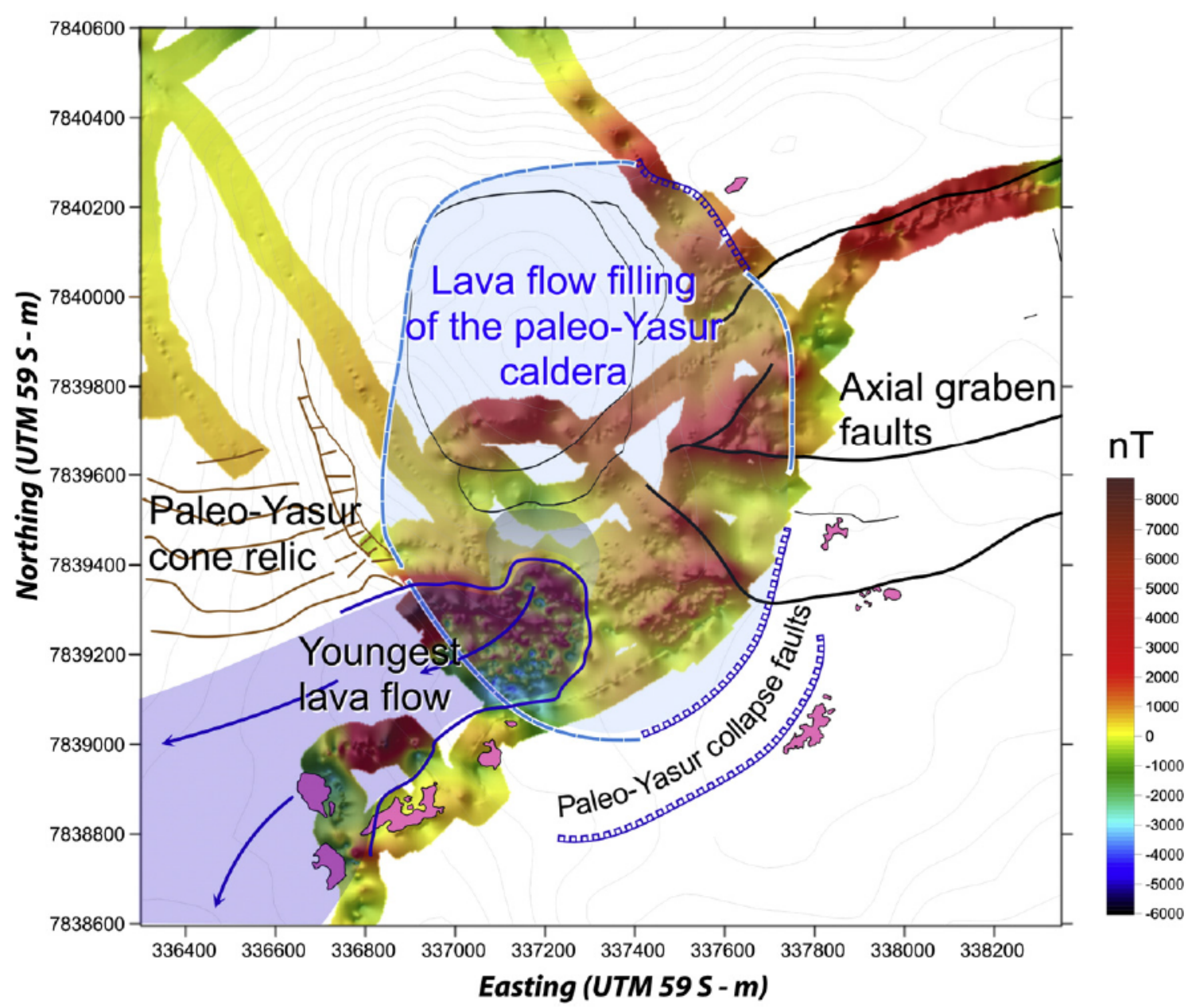

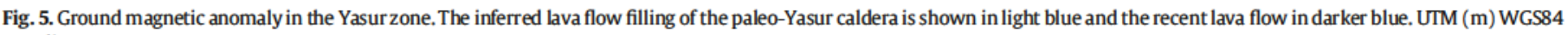
coordinates.

To the southeast of the eastern part of the resurgent dome, near the caldera boundary, a clear positive medium-wavelength magnetic anomaly is observed. It is located at a distance of $6 \mathrm{~km}$ on the profile shown in Fig. 4a. A map, using the few profiles available in this area, is shown in Fig. B.4a in Appendix B of the Supplementary Online Material. It is a well defined anomaly elongated along the caldera boundary. A simple 2D model (Fig. B.4b in Appendix B of the Supplementary Online Material) along the profile of Port Resolution shore indicates that the top of the body is close to the surface (tens of meters). The dimension of the source body can be estimated to about $400 \mathrm{~m}$ in width and $1 \mathrm{~km}$ in length. The magnetization contrast cannot be established, because the depth of the bottom is not constrained, but it appears to be significantly high ( $15 \mathrm{~A} \mathrm{~m}^{-1}$ for the model shown on Fig. B.5 in Appendix B, Supplementary Material). The geological interpretation of this magnetic body is speculative. It is difficult to consider it is associated with a large intrusion, owing to its shallow roof. Its confinement by the caldera rim suggests an accumulation of effusive products, possibly from the old Ombus cone.

A reduced to the pole (RTP) map was calculated after the whole data was upwardly continued to an elevation of $380 \mathrm{~m}$ (Fig. B.5 in Appendix B of the Supplementary Online Material). Negative anomalies on RTP maps indicate the presence of rocks with a reverse magnetization. It therefore appears that the northern part of the caldera is underlain by formations predating the Brunhes-Matuyama reversal $(0.78 \mathrm{Ma})$. This is fully compatible with the known ages of old formations on Tanna Island (Carney and Macfarlane, 1979).

\subsection{Resistivity structure (ERT, TDEM)}

Resistivity distribution in the Siwi caldera has been investigated in specific areas using electrical resistivity tomography (ERT; Fig. 2c) and time domain electro-magnetics (TDEM, Fig. 2d). Cross-sections, resulting from 2D inversion in ERT (Appendix D, Supplementary Online Material) and from interpolation between 1D soundings in TDEM (Appendix E, Supplementary Online Material), exhibit a large range of resistivity values from highly conductive (a few ohm $\mathrm{m}$ ) to resistive terrains (a few thousand ohm $\mathrm{m}$ ). In this volcanic context, low resistivity values can be associated with one or more of the following parameters (e.g. Kauahikaua, 1993; Lénat, 1995): hydrated minerals such as clay minerals and zeolites created by hydrothermal alteration, water contaminated by the ionic content of hydrothermal fluids, elevated temperature, sea water, and magma. Conversely, high resistivity values are usually associated with dry or water-unsaturated rocks, poorly permeable rocks or vapor-dominated zones.

\subsubsection{The Siwi caldera}

ERT profile A (Figs. 2c, 6) runs from the outside of the Siwi caldera, to the NW, to the southern foot of Yasur, to the SE. Two major conductive zones can be distinguished at depth, $C_{1}$ and $C_{2}$ on Fig. 6 , with typical values of a few tens of ohm $\mathrm{m}$. They encompass the rim of the Siwi caldera and the border of the Yenkahe resurgent dome, respectively. One can therefore suspect a causative relationship between these faults 

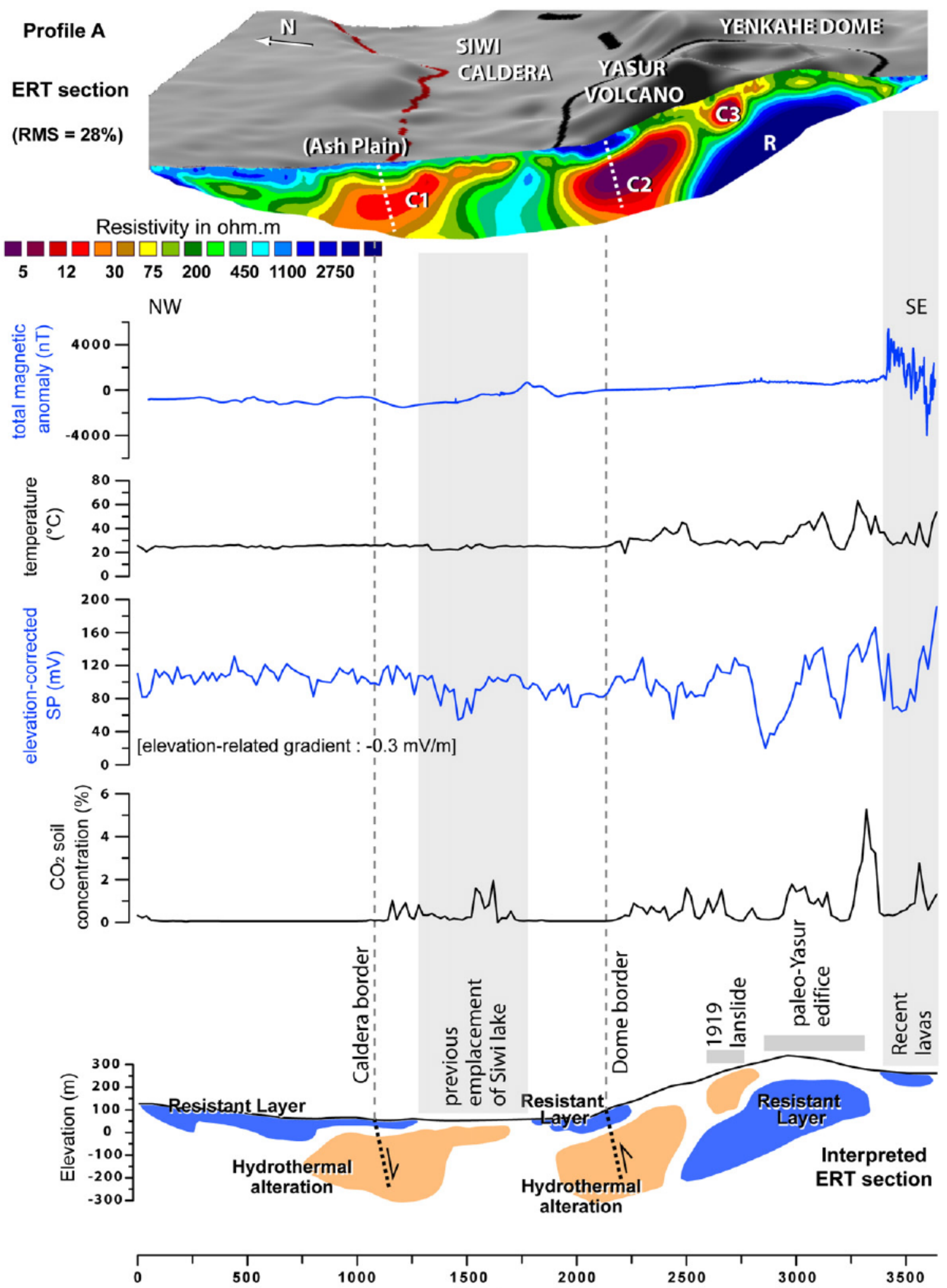

Distance (m)

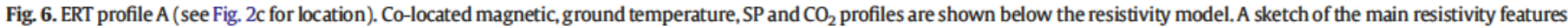
is shown at the bottom. Dashed lines indicate the location of assumed major faults. ERT inversion RMS error $=28 \%$.

and hydrothermal circulation which would explain such low resistivities. In the whole "Ash Plain" area (Figs. 1, 6), to the NW of the Yasur cone, the profile shows a resistant superficial layer characterized by resistivity values ranging from $\sim 500 \mathrm{ohm}$ m to several thousands of ohm $\mathrm{m}$, and a thickness varying from a few tens of meters to a hundred meters locally. This part of the profile coincides with the location where most ashes emitted during explosions accumulate because of dominant winds. This permeable and dry ash layer, outcropping in the Siwi river 
bed (Nairn et al., 1988; Firth et al., 2014), probably constitutes most of the shallow resistant layer of the ERT profile. This is also consistent with the smooth variations of the magnetic profile in this area (Fig. 6).

The two major conductive zones $C_{1}$ and $C_{2}$ are not associated with any strong peaks in the self-potential (SP), thermal or $\mathrm{CO}_{2}$ signals at the surface of the Ash Plain. This suggests poorly active hydrothermal circulation, or even fossil circulation, along the associated faults. However, Lardy and Tabbagh (1999) found abnormally high heat flux near the limit of the caldera in this area. As will be shown in Section 4.4, SP anomalies actually exist on a larger scale. The south-eastern shallow lateral extension of $C_{1}$ within the caldera coincides with the former location of the Siwi lake (naturally drained in 2000), where Nairn et al. (1988) identified a hydrothermal signature in the chemistry of the lake water. This is the only locality on the plain where a $\mathrm{CO}_{2}$ signal is observed.

In TDEM, only profile $\mathrm{T} 1$ allows the study of the caldera and its border (Fig. 7; Fig. E.2 in Appendix E of the Supplementary Online Material). Its northern part indicates that the floor is covered by about $50 \mathrm{~m}$ of resistive rocks (about 250 to $2000 \mathrm{ohm} \mathrm{m}$ ). This is consistent with the ERT pattern on profile A (Fig. 6) and the hypothesis of ash

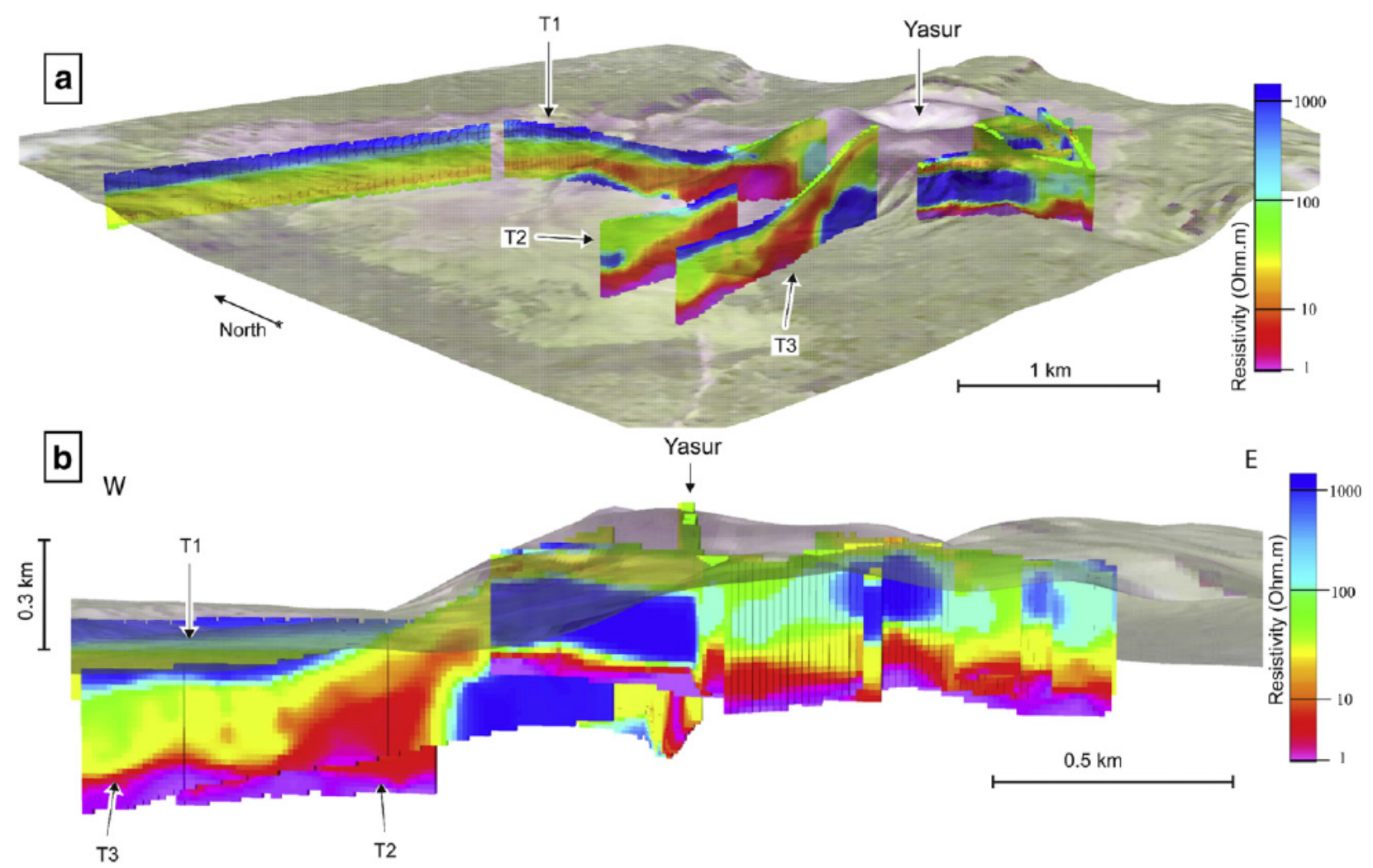

C

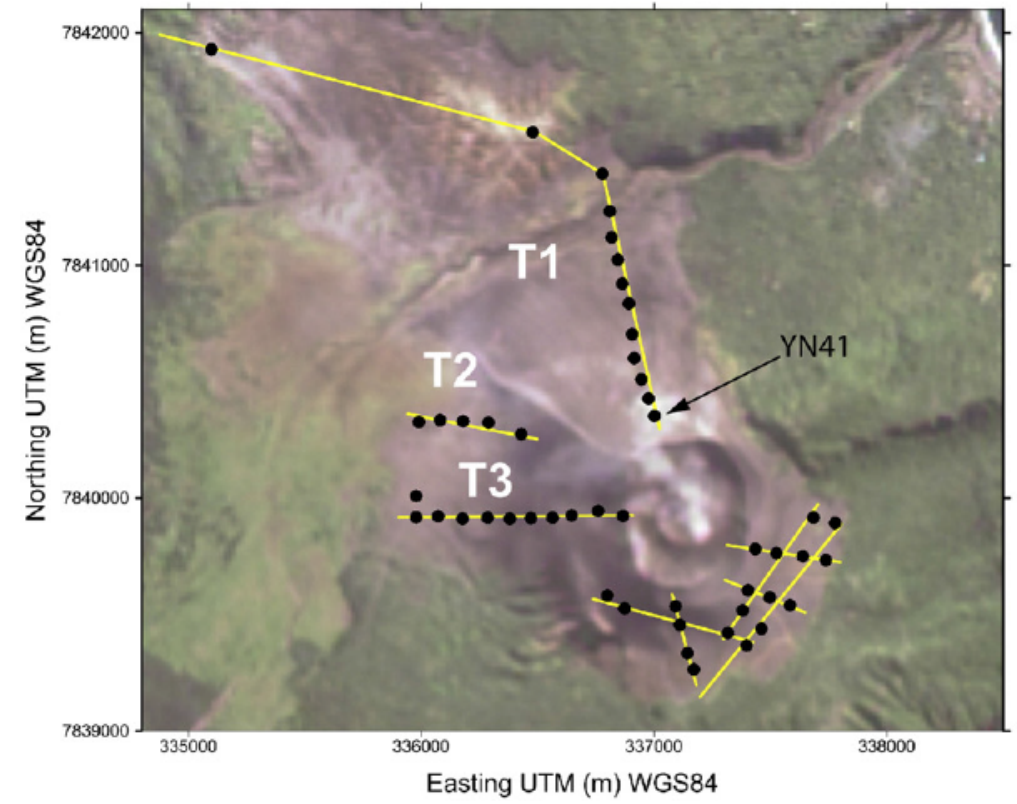

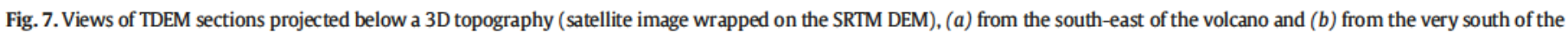
volcano. Locations of 1D soundings and profiles are shown in (c). UTM (m) WGS84 coordinates. 
accumulation. This resistant superficial layer may also reflect the presence of massive lava flows evidenced by magnetic data to the very north of the Yasur cone (Fig. 4). Below $50 \mathrm{~m}$, the resistivity decreases to $\sim 60 \mathrm{ohm} \mathrm{m}$, then deeper, to $\sim 25 \mathrm{ohm} \mathrm{m}$. At around $150 \mathrm{~m}$ in depth, a resistive terrain appears inside the caldera. From top to bottom, the transition from resistive to conductive rocks at a depth of about $50 \mathrm{~m}$ may be related to the presence of the water table near or slightly above sea level. The further decrease of resistivity below may be due to the presence of sea water, or hydrothermal contamination, or both.

With only two soundings outside of the caldera, this part is not well described. Surprisingly, the areas inside and outside the caldera are not contrasting in terms of resistivity. This, of course does not mean that a lithology contrast does not exist, but that it does not correspond to a significant resistivity change. The main difference seems to be the presence of deep (about $-150 \mathrm{~m}$ in elevation) resistive terrains on the caldera side.

\subsubsection{The Yasur cone}

The upper part of the Yasur cone in ERT profile $A$ is made of moderately conductive layers (Fig. 6; 100-200 ohm m) with patches of more conductive rocks $(\sim 10-75 \mathrm{ohm} \mathrm{m})$. The natural sections of the cone inside the central crater show that it is mostly made of apparently dry, non welded layers of ash, cinders and blocks. A larger resistivity is usually expected for such formations in comparison to what is observed in ERT, and several factors could explain these moderate resistivities: moisture, presence of hydrothermal minerals ejected by explosions from a deeper hydrothermally altered zone, and contamination of the deposits by salt particles from the plume (e.g. Rosenberg, 1988; Witham et al., 2005). The conductive patches are probably associated with hydrothermal circulation, which is in agreement with the presence of thermal and $\mathrm{CO}_{2}$ anomalies on the ash cone (Fig. 6). Additionally, under the western flank of the Yasur cone, ERT profile A shows a small and very conductive body $C_{3}(\sim 10 \mathrm{ohm} \mathrm{m})$ which coincides

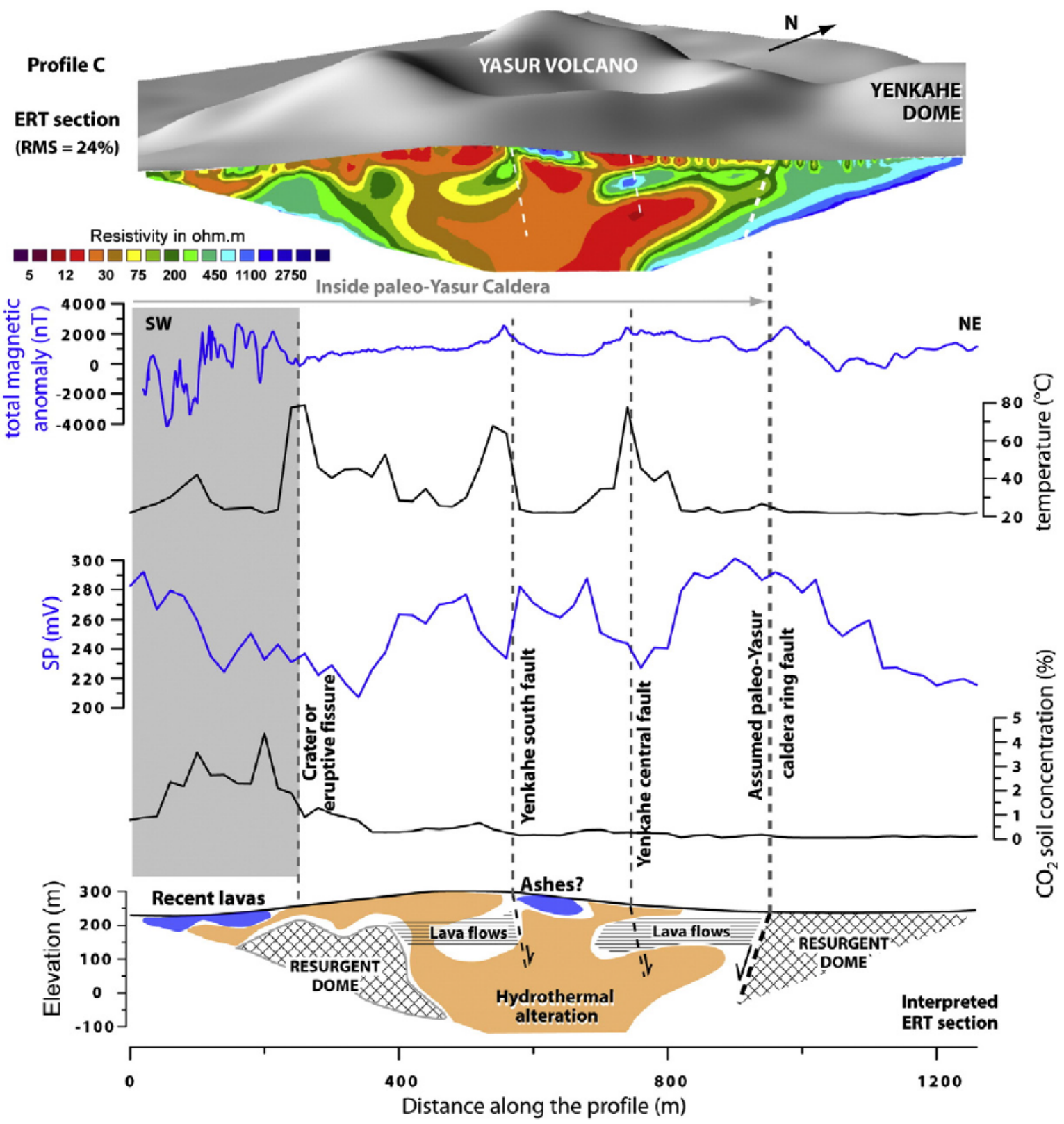

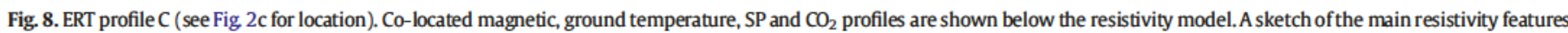
is shown at the bottom. Dashed lines indicate the location of faults. ERT inversion RMS error $=24 \%$. 
with the source area of the 1919 sector collapse (Brothelande et al., 2016a). The presence of hydrothermally altered rocks here could be the cause of the landslide or, alternatively, the scar of the landslide could have favored the channeling of hydrothermal fluids.

Though it is not well constrained by the data (Fig. D.1 in Appendix D of the Supplementary Online Material), the Yasur cone certainly lies on top of a large resistive body located 100 to $200 \mathrm{~m}$ below the surface (labeled $\mathrm{R}$ in Fig. 6). As suggested by gravity and magnetic data (see Sections 4.1,4.2), at least part of this resistive body could correspond to the infilling by lava flows of the paleo-Yasur caldera (Brothelande et al., 2016a; Merle et al., 2013). Recent lava flows outcropping at the south-eastern end of the profile are marked by high resistivities and high-amplitude short-wavelength magnetic signals ("youngest lava flows" in Fig. 5).

ERT profile $C$ cuts the south-eastern foot of the Yasur cone and the western part of the Yenkahe graben (Figs. 2c, 8). The central part of the profile is mostly occupied by conductive structures ( a few tens of ohm $\mathrm{m}$ ), probably reflecting the presence of hydrothermal fluids or a high concentration of hydrothermally altered rocks, with some more resistive patches ( $\mathrm{a}$ few hundred ohm $\mathrm{m}$ ). These patches form a more or less continuous horizontal layer about $70-100 \mathrm{~m}$ thick whose top is at a depth of about $50-100 \mathrm{~m}$. A similar resistive horizon is found in the
TDEM data (Fig. 7b; Fig E.2 in Appendix E of the Supplementary Online Material). As indicated above, the convergence of resistivity, magnetic and gravity anomalies suggests that this resistive horizon corresponds to lava flows filling the paleo-Yasur caldera. The Yenkahe South fault and the Yenkahe central fault, in the extension of the Yenkahe graben system (Brothelande et al., 2016a; Merle et al., 2013), coincide with temperature and SP signal variations (Fig. 8 and Peltier et al., 2012), but only the Yenkahe South fault corresponds to an obvious lateral contrast of resistivity. The edges of ERT profile $\mathrm{C}$ are overall more resistive. To the north-east, the limit of these resistive terrains (a few hundred to a thousand ohm $\mathrm{m}$ ) coincides with the presumed location of the ring fault limiting the paleo-Yasur caldera (Brothelande et al., 2016a; Merle et al., 2013). To the south-west, resistive terrains could represent the limit of the paleo-Yasur caldera in this area or a terrace in the fault system of the caldera collapse (Fig. 8). Superficial layers inside the presumed paleo-Yasur caldera exhibit low resistivity values (a few tens of $\mathrm{ohm} \mathrm{m}$ ) due to intense hydrothermal alteration, except a few patches probably related to ash accumulation and recent lavas (north-east of the Yenkahe South fault).

The Yasur cone and its surroundings are more densely covered by TDEM than ERT (Figs. 2c, d, 7c). Both methods agree on the upper part of the present cone being made up of moderately conductive layers

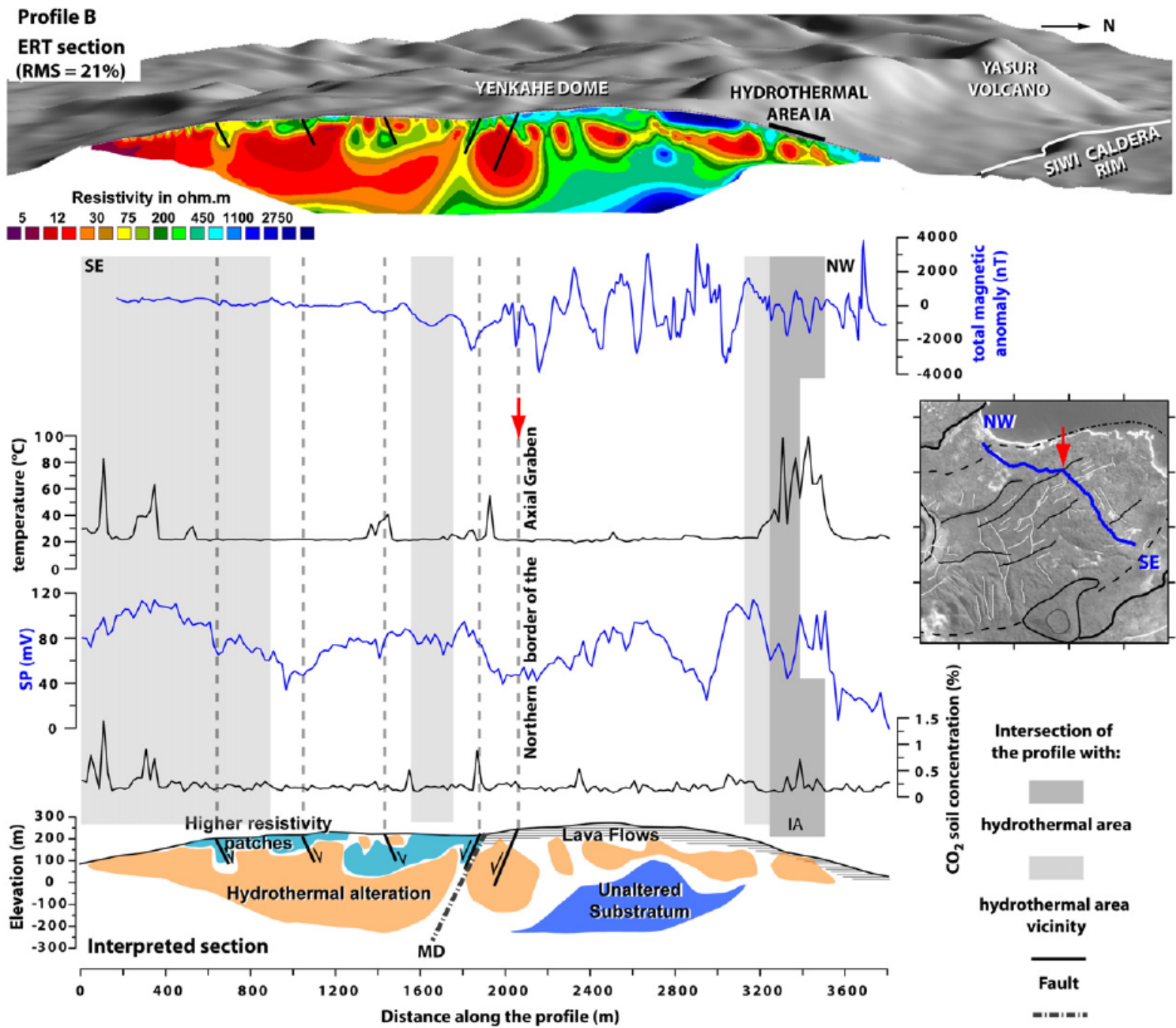

MD : Main resistivity discontinuity

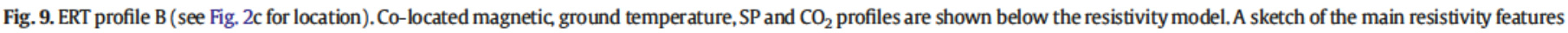

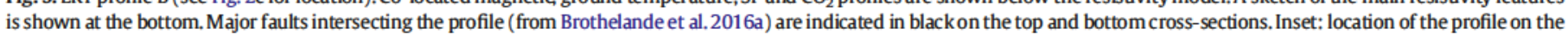
structural map (see Fig. 1). The northern edge of the axial graben is indicated by a red arrow. ERT inversion RMS error $=21 \%$ 
(40-60 ohm m, Fig. 7a). At about 50 to $150 \mathrm{~m}$ in depth, more resistive terrains appear, as suggested by ERT. However we observe differences between the northern and western slopes and the southern and south-western slopes. The northern and western slopes are sited on the inferred boundaries of the resurgent dome (Fig. 1). On the southern and eastern ends of TDEM profiles T1 and T3, respectively (Fig. 7; Fig. E.2 in Appendix E of the Supplementary Online Material), the cone lies on significantly more resistive terrains $(100-1000 \mathrm{ohm} \mathrm{m})$. Both profiles exhibit a sharp resistivity contrast towards the outside of the dome: a conspicuous, 250-300 m-wide protrusion of highly conductive rocks ( $<10 \mathrm{ohm} \mathrm{m}$ ), culminating about $80 \mathrm{~m}$ from the surface, seem to correspond to the inferred boundary of the resurgent dome. Despite the distance between profiles, we can reasonably assume a lateral continuity of this pattern: indeed, the same resistivity contrast is observed between $R$ and C2 on ERT profile A located in between (Fig. 6), and the continuity of the conductive body is confirmed on the eastern edge of TDEM profile $\mathrm{T} 2$. Such low conductivity values are probably related to a hydrothermally altered zone coinciding with the border fault of the resurgent dome.

Below the southern and south-western slopes of the cone, a marked resistive layer (100-10,000 ohm $\mathrm{m}$ ) is present from depths ranging between $50 \mathrm{~m}$ and $0 \mathrm{~m}$ (corresponding to a $210-260 \mathrm{~m}$ elevation, Fig. 7). It constitutes a fairly continuous and rather horizontal layer with a thickness of $100-150 \mathrm{~m}$, overlying highly conductive terrains ( $<10 \mathrm{ohm} \mathrm{m}$ ). Highly resistive values indicate the presence of dry, unaltered rocks. The shape and distribution of this unit suggest the infilling of the postulated paleo-Yasur caldera (Brothelande et al., 2016a; Merle et al., 2013) by a sequence of lava flows. In detail, the thick resistant layer is not perfectly homogeneous and it can be suspected that some of the faults with hydrothermal circulation that cross this unit (Peltier et al., 2012) contribute to lower the resistivity in some areas. The highly conductive terrains below suggest the presence of a strong pervasive hydrothermal alteration. This general pattern of resistivity is consistent with that observed on the ERT profile C (Fig. 8) and TDEM allows the observations to be extended over a larger area.

\subsubsection{The resurgent dome}

Apart from a few indications of hydrothermal alteration on its western border (Sections 4.3.1 and 4.3.2; Figs. 6, 7), most information on the structure of the Yenkahe is inferred from ERT profile B that crosses the eastern part of the resurgent dome (Fig. 2c). This profile exhibits two distinct domains in terms of resistivity patterns (Fig. 9). In the north-western part of ERT profile B, shallow resistivity values reaching a few thousand ohm $\mathrm{m}$ likely reflect the presence of massive, unaltered material. Widespread outcrops of massive lava flows observed in this area of the dome (Fig. 2e) and magnetic data (Section 4.3.2; Fig. 4) confirm this hypothesis. Well-resolved surface resistant bodies are a few tens of meters to one hundred meters-thick. They are interrupted by deeper conductive bodies that locally reach the surface. These conductive bodies, with values of a few tens of ohm m or less, are representative of a scattered hydrothermal system under the northern flank of the dome. The upward progression of hydrothermal fluids is probably facilitated by the fault network affecting the dome (Fig. 9). Upper hydrothermalized levels generally correlate to hydrothermal areas at the surface, where hot fluid circulation is shown by positive temperature and SP anomalies (see Section 4.4). This is clearly the case for the IAlabeled zone, where the profile crosses one of the largest areas of hot highly-altered ground (see also Fig. B.2 of the Supplementary Online Material). At depth, rocks affected by hydrothermal alteration form a quasicontinuous conductive layer with a mean thickness of about $100-150 \mathrm{~m}$, between the surface lava flows and a possible, although poorly defined (Fig. D.1 in Appendix D of the Supplementary Online Material), unaltered substratum.

The south-eastern part of the dome, on the contrary, is largely dominated by very low resistivities $(\sim 10 \mathrm{ohm} \mathrm{m})$ reflecting the extensive hydrothermalization of this domain (Fig. 9). The hydrothermal system is deeply rooted, and also reaches shallow levels. The southernmost part of the profile exhibits very low resistivity values at the surface that can be related to the high density of hydrothermally altered areas along the structural border of the dome (see Section 4.4.1). Southernmost hydrothermal areas are related to thermal and $\mathrm{CO}_{2}$ anomalies suggesting that the southern border of the dome may play a significant role in driving hydrothermal and magmatic fluids towards the surface. The northern limit of this extensive hydrothermal system, which separates the two resistivity domains, is indicated as the major discontinuity MD on Fig. 9. MD coincides both with a change in surface lithologies (from lava to the north to volcanic tuff and marine sediments to the south) and with longitudinal normal faults on the northern edge of

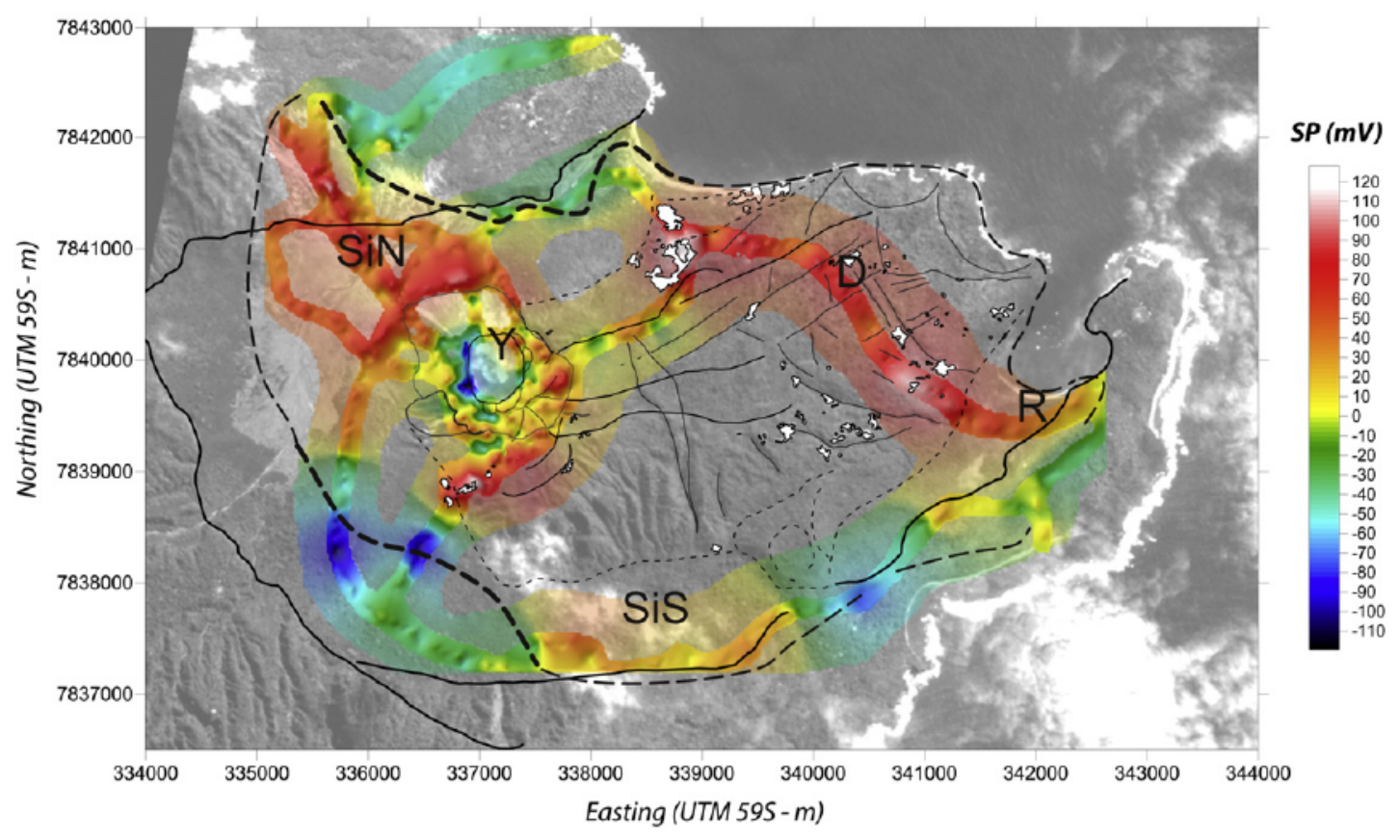

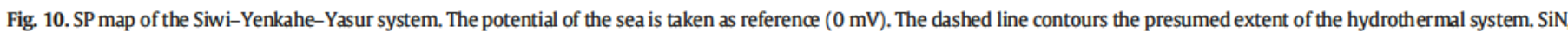
SiS, Y, D and R are major positive SP anomalies. UTM (m) WGS84 coordinates. 
the axial graben. These faults are related to temperature and $\mathrm{CO}_{2}$ anomalies: they channel the hydrothermal and magmatic fluid circulations and are probably deeply rooted into the dome. They may play an important role in limiting the lateral extension of the hydrothermal system.

\subsection{Fluid circulation ( $\mathrm{SP}$, temperature, $\mathrm{CO}_{2}$ degassing)}

The structural characterization of the Siwi-Yenkahe-Yasur system by geophysical methods was completed by techniques investigating the system dynamics in terms of hydrothermal activity (SP, temperature; Fig. 2c, d), and to a lesser extent, magmatic fluid circulation $\left(\mathrm{CO}_{2}\right.$ soil gas measurements).

\subsubsection{Hydrothermal circulations in the Siwi caldera}

Self-potential measurements were performed as a reconnaissance survey across the caldera with an electrode spacing of $50 \mathrm{~m}$ in 2004 , along ERT profiles with a $20-\mathrm{m}$ spacing, and in the Yasur area with a 10 -m spacing in 2008 (Fig. 2c, d). While the potential of the sea is taken as the reference $(0 \mathrm{mV})$, we note that a large part of the SP map exhibits positive values. In a purely hydrogeological context, one would expect to observe the usual inverse and linear relationship between SP and elevation. Inside the Siwi caldera, negative SP values are observed only to the west and around the Ombus and Yasur cones (Fig. 10). Fig. C.1 in Appendix C of the Supplementary Online Material shows the SP/elevation diagram of a SW-NE profile crossing the resurgent dome. In the SW part of the profile, a clear inverse and linear relationship between SP and elevation is observed up to the foot of the resurgent dome. The dome is characterized by an overall SP anomaly. Positive anomalies also exist outside the dome area such as SiS, SiN and R on Fig. 10. This suggests that in almost the entire caldera, an SP hydrothermal signal dominates over the hydrogeological one. The hydrothermal system is not restricted to the resurgent dome (with, in particular, the Y and D zones; Fig. 10), but it also expands to the NNW of Yasur ( $\mathrm{SiN}$ ), to the south (SiS) and to Port Resolution Bay (R). In the SiN zone, SP suggests that the hydrothermal system even extends beyond the caldera. The high heat flux $\left(0.7\right.$ to $\left.1.5 \mathrm{~W} \mathrm{~m}^{-2}\right)$ measured in this area by Lardy and Tabbagh (1999) supports this interpretation. In the $\mathrm{R}$ area, the presence of fumaroles and hot springs (Fig. 11; Carney
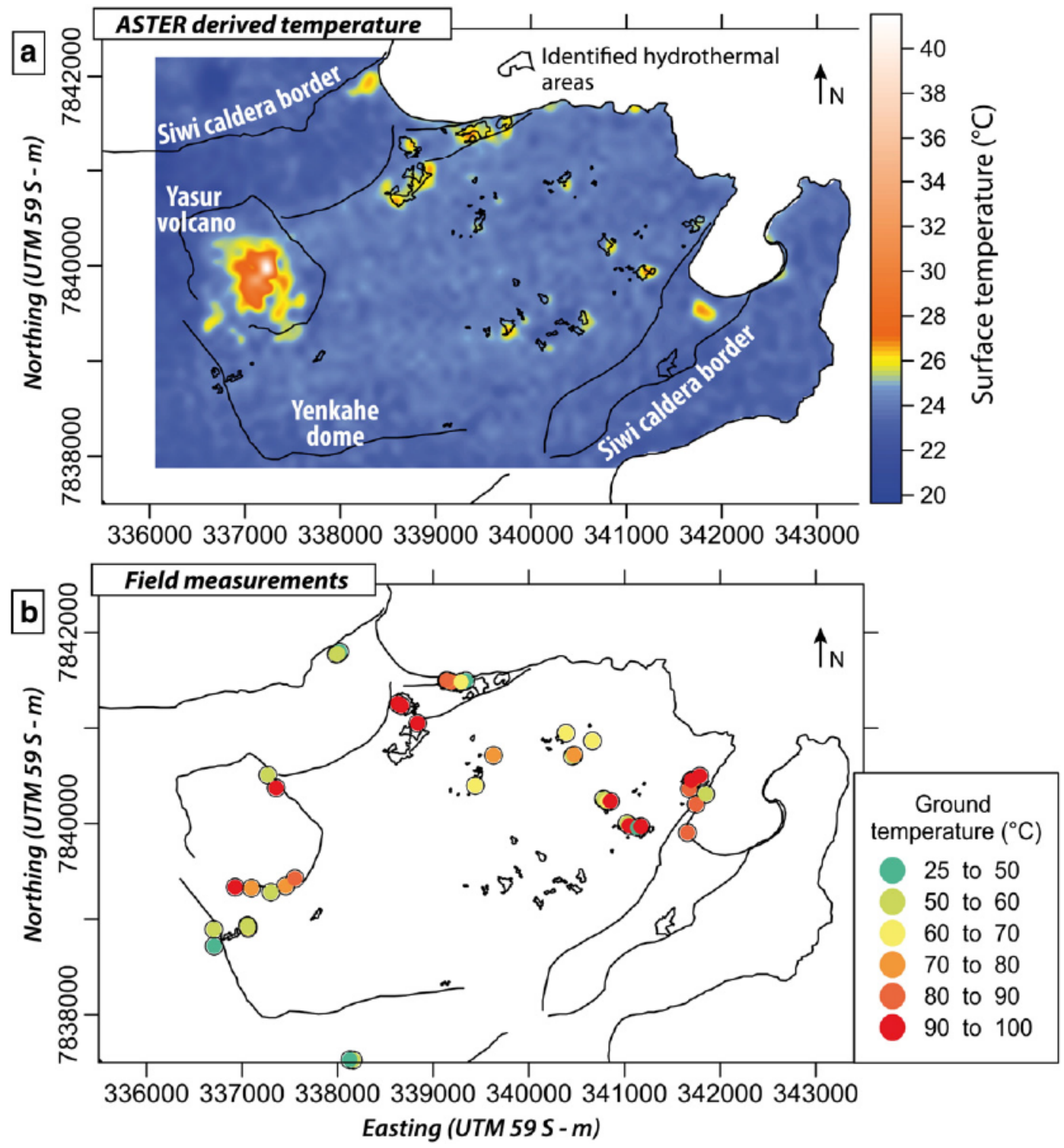

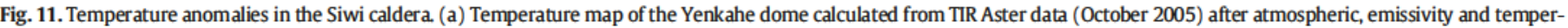

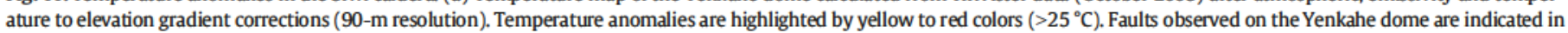
white. (b) Direct infrared thermometer measurements carried out in the field in June 2012 . Anomalous temperatures are $>25^{\circ} \mathrm{C}$. UTM ( $\mathrm{m}$ ) WGS84 coordinates. 
and Macfarlane, 1979; Gauthier et al., 2001; Nairn et al., 1988) also indicates hydrothermal activity.

Temperature measurements are complementary to SP data as they are directly related to the presence of a shallow hydrothermal system. A global temperature coverage of the dome was obtained from Aster thermal infrared data acquired in 2005 (October $31^{\text {st }}$ ), completed by ground infrared (IR) thermometer measurements (see Appendix F of the Supplementary Online Material). On Fig. 11, temperature anomalies observed in the Yasur area are mainly related to the volcanic plume that lies over the edifice due to its very frequent explosions. However, some of the low magnitude anomalies $\left(25-27^{\circ} \mathrm{C}\right)$ at the foot of the Yasur cone can be attributed to wellidentified fumarolic areas where ground IR thermometer measurements show abnormal temperatures (Fig. 11b). Outside of the Yasur area, most temperature anomalies have been observed in the field. Two anomalies have been found along the inner side of the caldera rim, close to the sea shore, due to the resurgence of hot water in the Siwi river (corresponding to the Ipikel Beach thermal area on Fig. 4) and in a small lake bordering Port Resolution bay. The ascension of hydrothermal fluids may be favored by the caldera ring fault. On the Yenkahe dome, temperature anomalies are always associated with hydrothermal areas characterized by the absence of vegetation (Brothelande et al., 2016a) and the presence of highly altered material. They are mainly located along its eastern border, and on its eastern part that appears to be much more active than the western one. The location of hydrothermal areas seems to be partly determined by the presence of faults, indicating a structural control of the hydrothermal circulation. The pixel size of Aster images $(90 \mathrm{~m})$ is generally much larger than the size of surface anomalies, but the estimation of the amplitude of thermal local anomalies was inferred from in situ IR thermometer data. Most ground anomalies range from 60 to $100^{\circ} \mathrm{C}$ (Fig. 11b).

Indications about $\mathrm{CO}_{2}$ degassing within the caldera are very sparse; we performed $20 \mathrm{~m}$-spaced measurements along ERT profiles. $\mathrm{CO}_{2}$ concentrations are always very low (maximum 9\%) indicating a generally low gas permeability in the area. Such an observation favors the hypothesis of the system self-sealing through hydrothermal alteration. Significant $\mathrm{CO}_{2}$ emanations (where concentrations $>1 \%$, reflecting magma degassing) are found at the site of the former Siwi Lake (Fig. 6), on the south-western part of the Yasur cone (Figs. 6, 8), on the periphery of the eastern Yenkahe dome and along a few faults of the axial graben (Fig. 9). Active dome borders and graben faults probably maintain a relatively high local permeability to magmatic gases.

\subsubsection{Fluid circulation in the Yasur area}

Concentric and radial SP profiles were performed on the Yasur cone with a 10 -m spacing, together with $\mathrm{CO}_{2}$ soil degassing measurements (Fig. 2d). These profiles and complementary measurements carried out along ERT profiles A and C (20-m spacing) offer a good coverage of the volcano (Figs. 12,13). The cone corresponds overall to a negative SP anomaly (with respect to the $0 \mathrm{mV}$ sea reference) onto which short wavelength anomalies are superimposed (Fig. 10).

The negative signature indicates that fluid circulation is dominated by hydrogeological processes (downward flow of meteoric water). This is what would be expected for a cone constructed by permeable rocks (non welded layers of ash, cinders and blocks). The SP/elevation gradient can be estimated at $\sim 0.3 \mathrm{mV} / \mathrm{m}$ (inset on Fig. 12). However, the south-eastern portion of the cone is dominated by positive SP values, indicating the preponderance of ascending hydrothermal flows

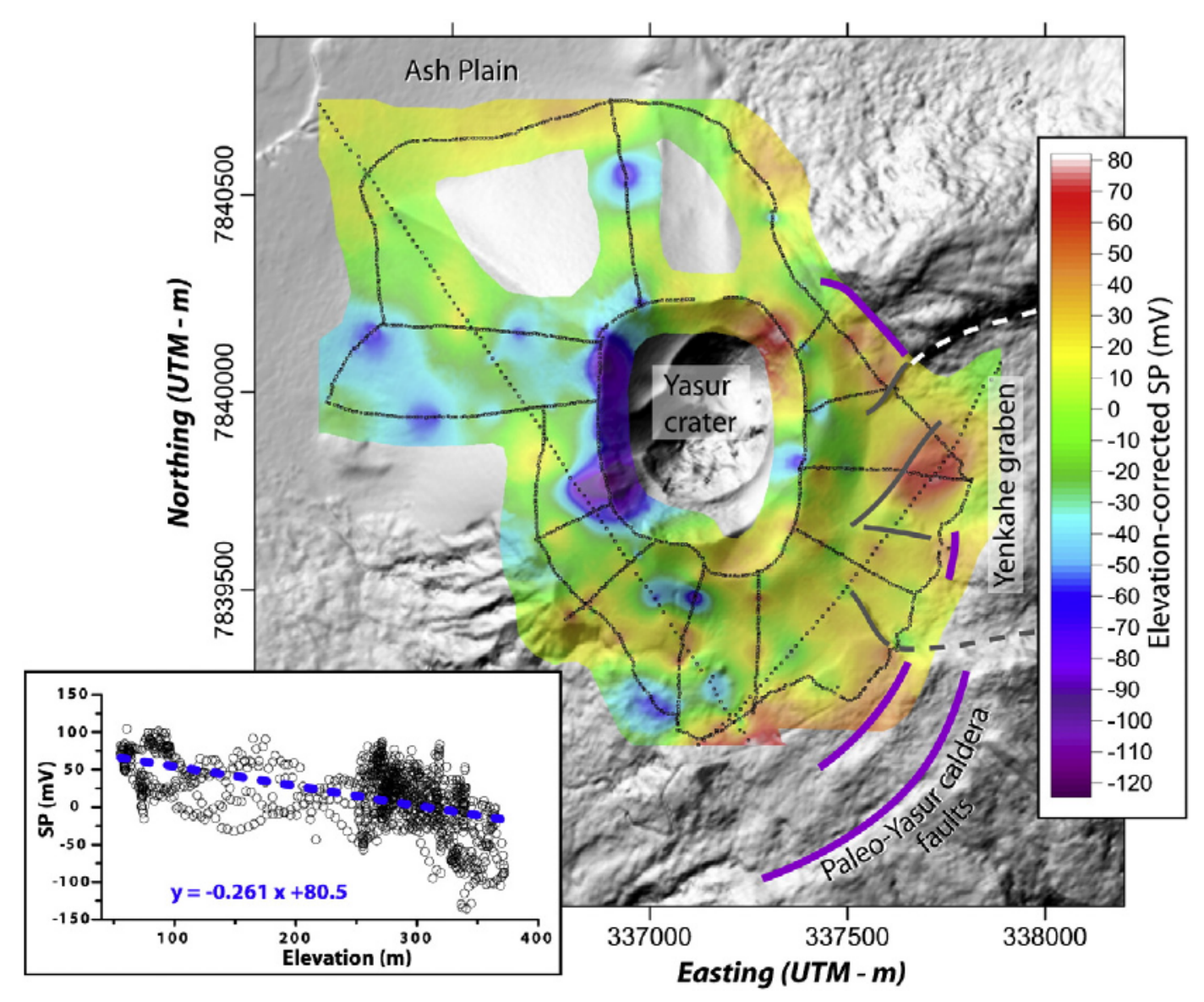

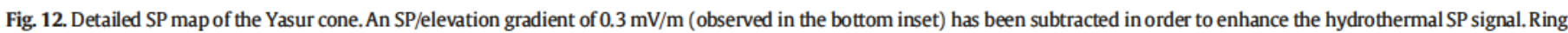
faults of the Paleo-Yasur caldera are marked in purple, and linear normal faults inside the small caldera in gray. UTM (m) WGS84 coordinates. 


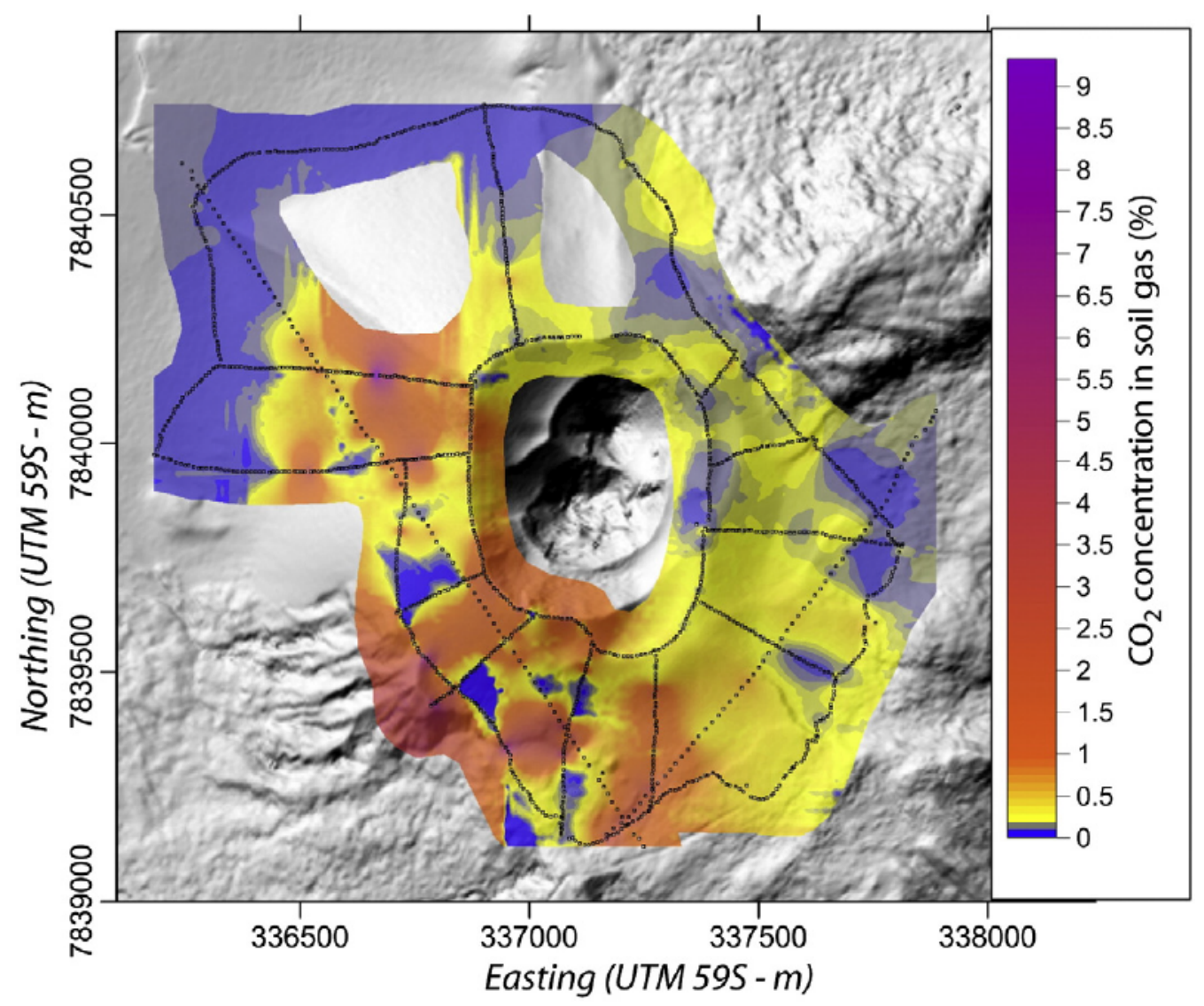

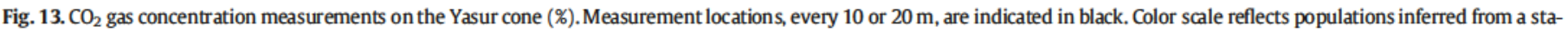

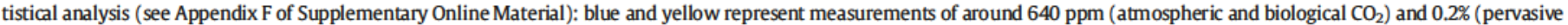

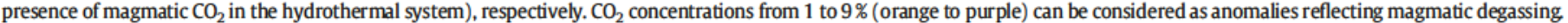
UTM (m) WGS84 coordinates.

in this area (Fig. 12). Positive anomalies are notably associated with ring faults of the paleo-Yasur caldera, with linear faults extending the graben system inside this caldera, and with the upper part of the cone (edges of craters and paleocraters). Most of these tectonic features are also associated with strong thermal anomalies as shown in Peltier et al., 2012, constituting permeable zones directing the upward flow of hydrothermal fluids through the edifice. This hydrothermal system, mostly confined to the paleo-Yasur caldera, as shown in Section 4.3.2, is eminently active.

The distribution of $\mathrm{CO}_{2}$ soil gas measurement anomalies on the unvegetated Yasur cone, from $1 \%$ up to more than $9 \%$, indicates that magmatic gas emanations predominate on the western side and do not follow preferential hydrothermal pathways (Fig. 13). Conversely, the opposite pattern observed on the eastern part of the Yasur area may be interpreted in terms of self-sealing of the hydrothermal system: the production of clays by high-level hydrothermal alteration has probably rendered the system impermeable to gas circulation despite the presence of faults.

\subsection{Synthetic combined interpretation}

Although our geophysical coverage is heterogeneous, it allows us to define major features of the internal structure and hydrothermal system of the Siwi-Yenkahe-Yasur system. We examine the western and eastern parts of the Yenkahe dome separately (Fig. 14), as significant differences exist between them.

The section on Fig. 14a runs SE-NW, crossing the western dome and the Yasur cone. As suggested by Carney and Macfarlane (1979), gravity, magnetic and resistivity data indicate the presence of a small caldera beneath the present-day Yasur cone (paleo-Yasur Caldera). The filling of this trough by lava flows is demonstrated by the presence of rocks with higher resistivity, magnetization and density than the surrounding ones (Figs. 3a, 4b, 7). High conductivity values beneath the lava flow filling can be attributed to the intense hydrothermal alteration of rocks and to the presence of hot geothermal fluids. The geothermal system seems to be channeled within the Paleo-Yasur caldera, probably because of the joint effect of more permeable rocks (fractured during the collapse) and the vicinity of the magmatic conduit of the Yasur. Hydrothermal fluids reach the surface through faults related to the resurgent dome and paleocraters, as has been shown by the high resolution soil temperature map of Peltier et al. (2012). No geophysical information is available for the resurgent dome south-east of Yasur. Between the foot of the resurgent dome and the Siwi caldera ring fault, the schematic profile of Fig. 14a crosses the southern lava flow field, well mapped on the magnetic survey. These lava flows may be observed in outcrops along the road. High SP values indicate hydrothermal circulation in this lava field (SiS, Fig. 10). The area to the NW of Yasur is well covered by geophysical data (Fig. 2). The limit of the Siwi caldera is well defined both topographically and on the gravity map (Fig. 3a). Conversely, it is not clear in the resistivity, SP and magnetic signals (Figs. 4b, 6, 10). The amplitude of the collapse is therefore difficult to establish. In gravity models, it strongly depends upon the density contrast assumed between the basement and the infilling of the caldera. Because this value is not known, the total collapse height remains unresolved. The caldera ring fault and the external faults of the resurgent dome (their existence is inferred from resurgence models; Acocella et al., 2001; Brothelande and Merle, 2015) are associated with large conductive bodies (Fig. 6). Owing to the low resistivity of the latter, they can be unambiguously 

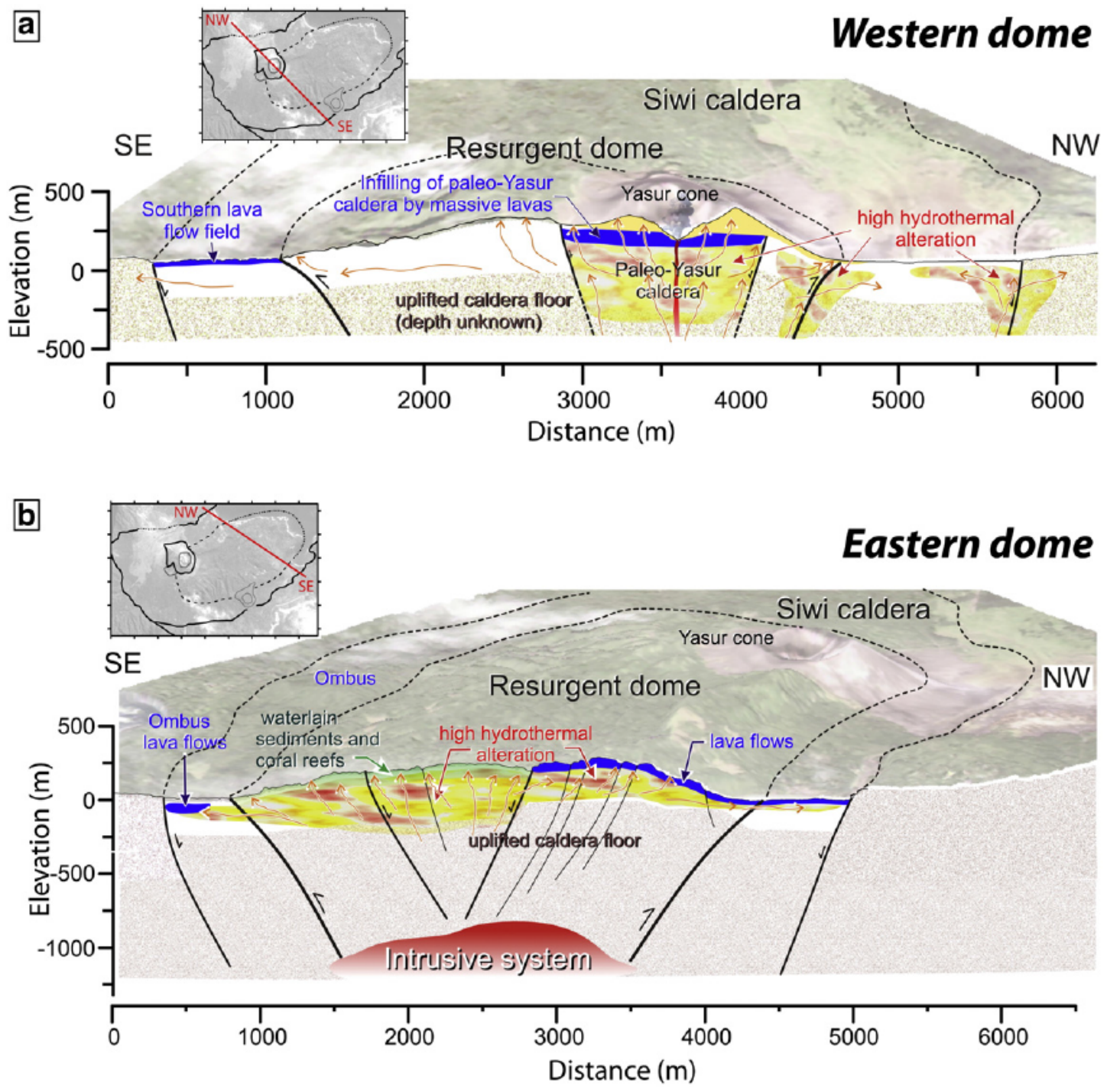

Fig. 14. Schematic cross-sections cutting the western (a) and eastern (b) parts of the Yenkahe dome illustrating the different structures evidenced by geophysical data.

identified with hydrothermally altered rocks and/or the presence of hydrothermal fluids. The hydrothermal activity in this area is also strongly supported by the clear positive SP signal (Fig. 10).

The profile on Fig. 14b runs SE-NW across the eastern part of the resurgent dome. At the surface, a clear lithological contrast exists between the lava flows to the NW and the sedimentary formations to the SE. Beyond the dome, close to the Siwi limit, a magnetic body is inferred to be lava flows emitted by the Ombus volcano. The interior of the resurgent dome in this area is dominated by the widespread presence of low resistivity rocks. They correspond to highly altered rocks that can be observed at the surface at numerous active hydrothermal areas associated with thermal anomalies. The active state of the hydrothermal system is also attested by the huge wavelength positive SP anomaly located on the Yenkahe dome (see "D" on Fig. 10). The alteration ranges from moderate to total transformation to colorful clays. Whereas the highly altered zone extends at least down to the base of the resurgent dome in its south-eastern half, it forms a thinner layer beneath the lava flows in the north-eastern half. This huge difference in alteration between the two zones, observed from the surface up to $\sim 400 \mathrm{~m}$ depth (maximum penetration depth for the ERT profile), is not well explained as the contrast coincides with both superficial lithology changes and the presence of faults constituting the northern edge of the axial graben. This contrast shows that the SE part of the resurgent dome is far more prone to gravitational instability owing to the much more altered state of the rocks. As shown by the thermal map (Fig. 12a) and the structural map of Brothelande et al. (2016a), it is obvious that the eastern part of the resurgent dome is the most active in terms of tectonic and hydrothermal activities. This implies that the source of deformation, heat and fluids is also dynamic in this area. Gravity models cannot resolve the presence and location of the intrusive system assumed to be the cause of the resurgence. However, Brothelande and Merle (2015) and Brothelande et al. (2016b) estimate the depth of the top of the intrusive system to be $1-2 \mathrm{~km}$, on the basis of analog and numerical simulations.

\section{Discussion}

Yenkahe is probably one of the most rapidly deforming resurgent domes on Earth. Chen et al. (1995) calculated a mean uplift rate of about $15 \mathrm{~cm} /$ year during the last millennium. Although the uplift may have a more or less continuous component, discrete events seem to account for most of the uplift (e.g. $\sim 10$ m coseismic uplift in 1878; Chen et al., 1995). Unlike most active volcanic resurgences (e.g. Long Valley, Phlegrean Fields, Ischia, Iwo-Jima, Rabaul, Yellowstone), no dense deformation and seismicity networks exist to monitor the SiwiYenkahe-Yasur complex. Therefore the mechanism and dynamics of the volcanic and volcano-tectonic activities can only be assessed using the available geological and geophysical information collected during 
surveys. Using previously published work and our new geophysical data, we can attempt to reconstruct the development and evolution of the system. Fig. 15 summarizes the inferred evolution of the area in 4 stages.

The age of the Siwi caldera is not known, but most authors suggest a relatively young age (less than 20,000 years for Nairn et al., 1988). As suggested for other calderas (e.g. Kennedy et al., 2012; Phillips et al., 2007; Sacchi et al., 2014), resurgence probably began soon after caldera collapse, due to the intrusion of magma underneath (dome and graben models support a fairly elongated structure from the beginning of resurgence; Brothelande and Merle, 2015). The northern lava field, probably uplifted on the northern flank of Yenkahe by the resurgence and affected by graben faulting, can be regarded as pre-dating most of the doming process. These lavas may have originated from an old edifice (protoYasur or paleo-Yasur ?) to which eroded terrains on the southwestern flank of the dome may belong (Brothelande et al., 2016a).

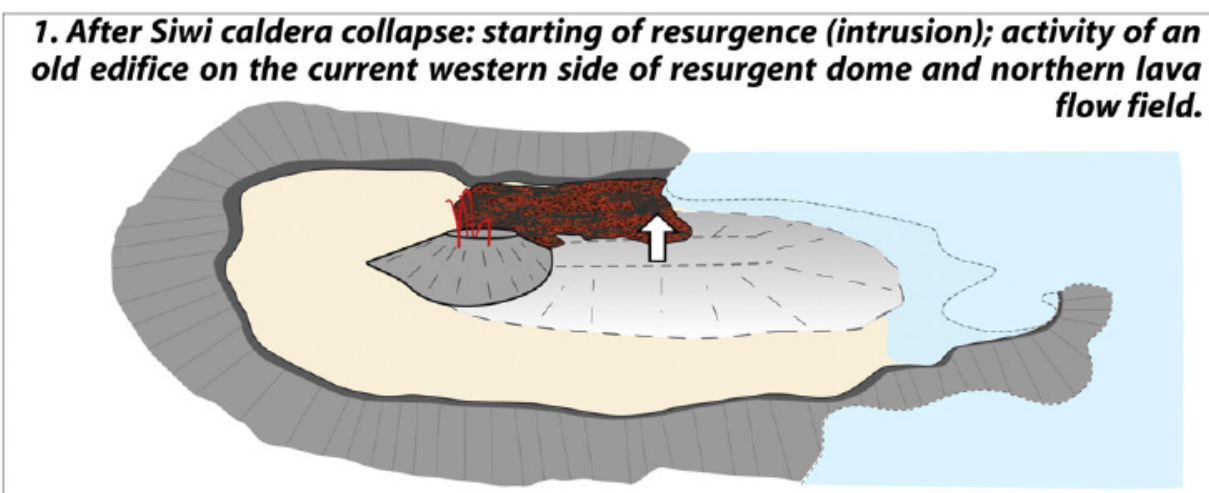

2. Continuing resurgence; Old edifice erosion; Ombus activity.

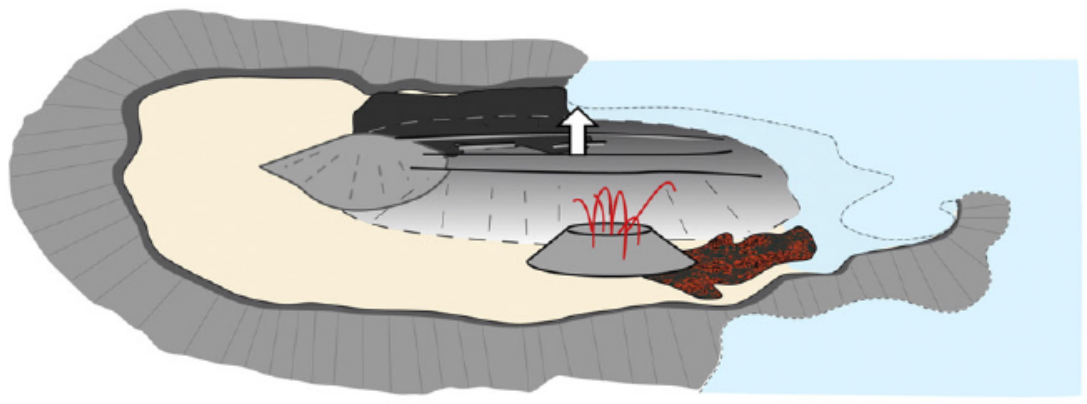

3. Paleo-Yasur caldera collapse related to eastward displacement of the resurgence (intrusion migration) or to the emplacement of the southern lava field ; possible collapse of the western part of the resurgent dome

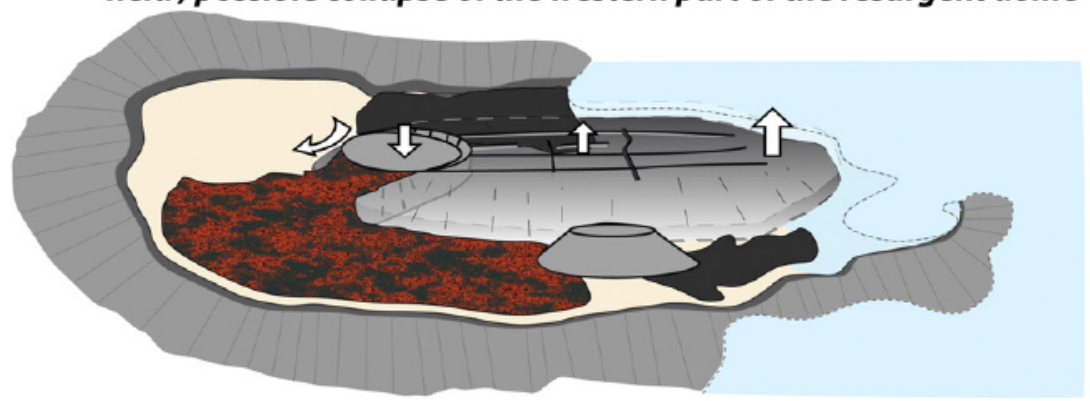

4. Yasur construction, minor lava flows ; continuing development of the

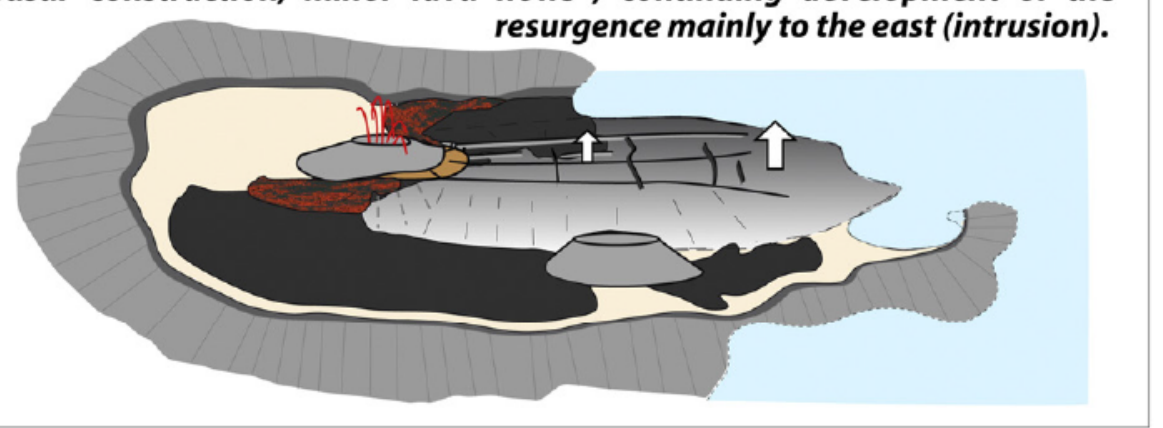

Fig. 15. Possible scenario for the post-collapse evolution of the Siwi caldera, inferred from available data. 
Stage 1 in Fig. 15 shows what could have been the first activities after caldera collapse: the start of resurgence, the eruptive activity of an old edifice, and the emplacement of the northern lava field. The relative chronology of these events cannot be resolved. Stage 2 represents further development of the resurgent dome, the formation of the Ombus edifice on its southern edge (not well-constrained in time) and the emplacement of lava flows, probably from the Ombus towards the sea, between the caldera rim and the dome border. Stage 3 marks major events in the evolution of the Yenkahe dome. The collapse of the paleo-Yasur caldera may have been caused by a lateral intrusion or by major effusive activity. If the recent uplift of the eastern part of the dome has been caused by a lateral northeastward-directed magma intrusion, as suggested by the dome fault pattern (Merle et al., 2013), this magma displacement would have drained a reservoir beneath the paleo-Yasur, leading to the collapse. On the other hand, the emplacement of the large southern lava flow field over a short period of time could also have drained a magma reservoir. With a surface area of about $6 \times 10^{6} \mathrm{~m}^{2}$, this lava flow field represents a volume of $60 \times 10^{6} \mathrm{~m}^{3}$, given a mean thickness of $10 \mathrm{~m}$. In addition, the interruption of the curved caldera faults at the W-SW border of the resurgent dome (Brothelande et al., 2016a) suggests that the border of the dome here may have partially collapsed during or after the caldera formation. Lastly, stage 4 represents the recent activity, with the construction of the Yasur cone (probably 800 to 1400 yrs-old; Firth et al., 2014) in the paleo-Yasur caldera partly filled with lavas, its effusive activity contributing to the southern lava flow field (and possibly to the northern one), and the continuing resurgence of the Yenkahe dome. As suggested earlier, resurgence seems much more dynamic on the eastern side of the dome. However, minor faults (a few meters high) affecting the paleoYasur caldera infill supports recent reactivation of the dome graben faults (Peltier et al., 2012). There was probably minor but persistent tectonic activity in the western dome in recent times.

This synthesis presents a possible scenario for the post-collapse history of the Siwi caldera, based on available data. Although its major weakness is the lack of absolute timing constraints for some of the inferred events, it may be regarded as a basis for further investigations. A major point is the inferred eastward migration and development of the resurgence, as suggested by Merle et al. (2013). Coexistence of this eastwardly migrating activity with the long-term steady activity of the Yasur volcano to the west (Nairn et al., 1988; Metrich et al., 2011; Firth et al., 2014), raises questions about the plumbing system associated with the Yenkahe and Yasur edifices, some of which are explored by Brothelande et al. (2016b).

Besides volcanism and tectonic resurgence, hydrothermal activity appears to be an important component of post-collapse unrest in the Siwi caldera. The extent of the hydrothermal system is relatively hard to define. Self-potential data supports the idea of a pervasive active system in most parts of the caldera, and even beyond its limits, arguing for the presence of relatively large heat sources at depth or centrifuge circulation from the resurgent dome. Lardy and Tabbagh (1999) measured heat fluxes 3 to 6 times greater than normal at two kilometers north of the volcano (the normal flux is estimated in a quiet zone $20 \mathrm{~km}$ away from the Siwi system). These fluxes, on the caldera border or just beyond, support the existence of a widespread hydrothermal activity. The same conclusion stems from the presence of hot water resurgence along the caldera borders (see Section 4.4.1). Nonetheless, thermal measurements show that the most active subsurface parts of this extended hydrothermal system are linked to the Yasur and Yenkahe edifices. Hydrothermal areas observed on the eastern part of the dome are probably long-lived systems because similar areas (perhaps the same) of warm ground covered with grass or clays and local fumaroles, were described by Cook and Furneaux (1777) at locations (uphill between Port-Resolution bay and the volcano) and with temperatures $\left(77-94^{\circ} \mathrm{C}\right)$ consistent with the present day. Long-lived hydrothermal activity provides an explanation for the high alteration level of the eastern part of the dome, as shown by the high electrical conductivity values observed in this area. The widescale development of the hydrothermal system at depth has several consequences. Firstly, pressurization of hydrothermal fluids may be the cause of short-term deformation cycles observed on the dome (Brothelande et al., 2016b), as it is the case at other resurgent calderas (e.g. Troise et al., 2007; Hurwitz et al., 2007; Chang et al., 2007). Secondly, the combination of a large hydrothermal system and relatively shallow magma intrusions suggests the possibility of phreatic or phreatomagmatic activity (although, as suggested by Metrich et al. (2011), the degassed magma of the intrusions has probably only a very low eruptibility). Thirdly, the presence of rocks with low cohesion (hydrothermally altered rocks, uplifted sediments) beneath the eastern part of the dome, coupled to a fast uplift rate, increases the threat of gravitational instability events affecting the dome. Such destabilizations may additionally trigger catastrophic tsunamis if they reach the sea; the shore-facing flank appears to be the most unstable one (Brothelande et al., 2016a). This type of event has been pointed out in other resurgent contexts such as Ischia (Tibaldi and Vezzoli, 2004). Tsunamis and landslides into Port Resolution bay have also already occurred during the last uplift episodes of the Yenkahe dome (Paton and Paton, 1894; Louat and Baldassari, 1989).

\section{Conclusions}

Caldera resurgence is a very important phenomenon in volcanology, because it involves interactions between magma, tectonics and hydrothermal systems. However, the mechanisms causing resurgence, as well as associated hazards, are still not fully identified in presently active systems. The Yenkahe dome offers a unique opportunity to study the general structure and the associated hydrothermal circulations inside of a moderate sized and very active resurgence.

Here, the approach is based on a multi-method study of the internal structure of the system using geophysical data. The study notably illustrates how gravity, magnetic and resistivity data may be used together to unambiguously identify structures such as lava fields or hydrothermalized layers, and delimit their horizontal and vertical extents. The interpretation of these structures in the Siwi caldera and their relative chronology shows that the formation of the Yenkahe dome results from complex interactions of tectonic, volcanic and hydrothermal processes. For the first time, a substantiated structural image of the system is proposed. Several lava fields and different volcanic edifices are identified within the caldera, showing that lava extrusion and tectonic resurgence have been operating simultaneously or alternately during the Siwi caldera post-collapse history, as reported in a few other calderas (e.g. Valles caldera, Smith and Bailey, 1968; Tomochic, Swanson and McDowell, 1985). The current close association between the Yasur volcano and the Yenkahe dome may not be an exception, and may reflect a long-lived association between resurgence and volcanism in the caldera. This association demonstrates the intensity of the magmatic activity beneath the dome, supporting the magmatic intrusion cause for resurgence. Long-term and large-scale $(156 \mathrm{~m}$ in $1,000 \mathrm{yrs}$ ) uplift must, indeed, result from a significant input of magmatic material at depth. Higher resurgence speed at Yenkahe in comparison to other resurgent domes (generally 2-3 cm/year; Phillips et al., 2007; Tibaldi and Vezzoli, 1998) is then certainly related to very high subduction rates in the region. Geophysical data have also demonstrated the presence of an extended hydrothermal system that account for part of the dome uplift, probably acting on shorter time periods. The importance of the deformation caused by hydrothermal systems has been pointed out in several cases (e.g. Yellowstone, Chang et al., 2007; Aly and Cochran, 2011; Phlegrean Fields, Acocella, 2010). For the moment though, very few information on short-term deformation at Yenkahe has been collected (Brothelande et al., 2016b). Hydrothermal alteration renders the edifice unstable. Low-cohesion material and large uplift episodes form a dangerous combination triggering landslides as in the example of Ischia (Tibaldi and Vezzoli, 2004). 
Several major issues about the Yenkahe dome are still unresolved. Further geophysical investigations (seismic tomography and magnetotelluric soundings) are still needed to unambiguously detect the potential presence of a magmatic intrusion as being at the origin of the resurgence. Precise dating of lava flows in the area would be a great help to unravel the volcano history. Finally, a gravimetric study at a larger scale would be necessary in the future to better constrain the regional gravity field and to extend the resolution of the models at depth. From the methods we used, the presence of an extended and very active hydrothermal system on the dome is probably the best indicator, the clearest we can have, of a probably shallow magmatic body underneath. Higher hydrothermal activity on the western dome may signify a superficial or more active magmatic source under this part. More in-depth methods of investigation would be necessary to resolve the ambiguity. This is probably the main challenge for future investigations, because the interplay between the parts of the plumbing system that supply magma to the Yasur activity and to the resurgence intrusion is crucial in understanding the functioning of such a volcanic system. Besides this structural information, monitoring the deformation, seismicity and fluids over the whole area is essential in terms of investigating the dynamics of the system.

Supplementary data to this article can be found online at http://dx. doi.org/10.1016/j.jvolgeores.2015.08.021.

\section{Acknowledgments}

We thank Bernard Pelletier (I.R.D) for his help in organizing the 2008 field campaign, Adrien Normier and Clémentine Bacri (O.R.A., Wings for Science) for providing us with aerial imagery, Andrew Harris (Laboratoire Magmas et Volcans, Clermont Ferrand) and Eric Delcher (Laboratoire Géosciences Réunion) for their help in data exploitation. Constructive reviews were provided by Jean Vandemeulebrouck and an anonymous reviewer. We thank the guest editor Sylvie Vergniolle for fruitful discussion. This research was co-financed by the French Government "ANR ARC-Vanuatu: Programme Catastrophes Telluriques et Tsunamis" (ANR-06-CATT-02) and Laboratory of Excellence initiative $n^{\circ}$ ANR-10-LABX-0006, the Laboratoire Magmas et Volcans (LMV), the Laboratoire GéoSciences Réunion, the Région Auvergne and the European Regional Development Fund. Datasets are available at LMV. In addition, gravimetric data are available at International Gravimetric Bureau. This is Laboratory of Excellence ClerVolc contribution number 171 and IPGP contribution number 3654.

\section{References}

Acocella, V, 2010. Evaluating fracture patterns within a resurgent caldera: Campi Flegrei, Italy. Bull. Volcanol. 72, 623-638. http://dx.doi.org/10.1007/s00445-010-0347-x.

Acocella, V., Cifelli, F., Funiciello, R., 2001. The control of overburden thickness on resurgent domes: insights from analogue models. J. Volcanol. Geotherm. Res. 111, 137-153. http://dx.doi.org/10.1016/S0377-0273(01)00224-4.

Allen, S.R., 2004. Complex spatter- and pumice-rich pyroclastic deposits from an andesitic caldera-forming eruption: the Siwi pyroclastic sequence, Tanna, Vanuatu. Bull. Volcanol. 67 (1), 27-41.

Aly, M.H., Cochran, E.S., 2011. Spatio-temporal evolution of Yellowstone deformation between 1992 and 2009 from InSAR and GPS observations. Bull. Volcanol. 73, 1407-1419. http://dx.doi.org/10.1007/s00445-011-0483-y.

Aubert de la Rüe, E., 1960. Les manifestations actuelles du volcanisme aux Nouvelles Hébrides (Mélanésie). Bull. Volcanol. 23, 197-205.

Bani, P., Lardy, M., 2007. Sulphur dioxide emission rates from Yasur volcano, Vanuatu archipelago. Geophys. Res. Lett. 34 (20).

Bani, P., Harris, A.J.L., Shinohara, H., Donnadieu, F., 2013. Magma dynamics feeding Yasur's explosive activity observed using thermal infrared remote sensing. Geophys. Res. Lett. 40 (15), 3830-3835. http://dx.doi.org/10.1002/grl.50722.

Battaglia, J., Métaxian, J.-P., Garaebiti, E, 2012. Earthquake-volcano interaction imaged by coda wave interferometry. Geophys. Res. Lett. 39, L11309. http://dx.doi.org/10.1029/ 2012 gl052003.

Blot, C., Tazieff, H., 1961. Quelques résultats de séismologie volcanique au volcan Yahue, dans l'île de Tanna. (Nouvelles-Hébrides). Bull. Séances Acad. R. Sci. Outre Mer Brux. 7 (2), 270-279.

Bouligand, C., Glen, J.M.G., Blakely, R.J., 2014. Distribution of buried hydrothermal alteration deduced from high-resolution magnetic surveys in Yellowstone National
Park. J. Geophys. Res. Solid Earth 119, 2595-2630. http://dx.doi.org/10.1002/ 2013JB010802.

Brothelande, E., Merle, O, 2015. Estimation of magma depth for resurgent domes: an experimental approach. Earth Planet. Sci. Lett. 412, 143-151. http://dx.doi.org/10.1016/ j.epsl.2014.12.011.

Brothelande, E., Finizola, A., Peltier, A, Delcher, E., Komorowski, J.-C., Di Gangi, F., Borgogno, G., Passarella, M., Trovato, C., Legendre, Y, 2014. Fluid circulation pattern inside La Soufrière volcano (Guadeloupe) inferred from combined electrical resistivity tomography, self-potential, soil temperature and diffuse degassing measurements. J. Volcanol. Geotherm. Res. 288, 105-122. http://dx.doi.org/10.1016/j.jvolgeores. 2014.10.007.

Brothelande, E., Lénat, J.-F., Normier, A, Bacri, C., Peltier, A., Paris, R, Kelfoun, K., Merle, O, Finizola, A., Garaebiti, E., 2016a. Insights into the evolution of the Yenkahe resurgent dome (Siwi caldera, Vanuatu) inferred from aerial high-resolution photogrammetry. J. Volcanol. Geotherm. Res, 322, 212-224.

Brothelande, E., Peltier, A., Got, J.-L., Merle, O., Lardy, M., Garaebiti, E., 2016b. Constraints on the source of resurgent doming inferred from numerical and analogue modeling: the case study of the Yenkahe dome (Vanuatu). J. Volcanol. Geotherm. Res. 322, 225-240.

Calmant, S., Pelletier, B, Lebellegard, P., Bevis, M. Taylor, F.W., Phillips, DA., 2003. New insights on the tectonics along the New Hebrides subduction zone based on GPS results. J. Geophys. Res. 108 (B6), 2319-2339.

Campos-Enriquez, J.O, Arredondo-Fragoso, JJ., 1992. Gravity study of Los Humeros caldera complex, Mexico: structure and associated geothermal system. J. Volcanol. Geotherm. Res. 49, 69-90.

Carney, J.N., Macfarlane, A., 1979. Geology of Tanna, Aneityum, Futana and Aniwa New Hebrides Government Geol Survey Report. pp. 5-29.

Chang, W.-L., Smith, R.B., Wicks, C., Farrell, J.M., Puskas, C.M., 2007. Accelerated uplift and magmatic intrusion of the Yellowstone caldera, 2004 to 2006. Science 318, 952-956. http://dx.doi.org/10.1126/science.1146842.

Chen, JK., Taylor, F.W., Edwards, R.L., Cheng, H., Burr, G.S., 1995. Recent emerged reef terraces of the Yenkahe Resurgent Block, Tanna, Vanuatu-implications for volcanic, landslide and tsunami hazards. J. Geol. 103 (5), 577-590.

Cook, J., Furneaux, T., 1777. A Voyage towards the South Pole and Round the World. Performed in His Majesty's Ships the Resolution and Adventure, In the years 1772, 1773, 1774 and 1775. Strahan and Cadell.

Du Bray, E.A., Pallister, J.S, 1999. Recrystallization and anatexis along the plutonic-volcanic contact of the Turkey Creek caldera, Arizona. Geol. Soc. Am. Bull. 111, 143-153.

Firth, C.W., Handley, H.K., Cronin, C.J. Turner, S.P., 2014. The eruptive history and chemical stratigraphy of a post-caldera, steady-state volcano: Yasur, Vanuatu. Bull. Volcanol. 76, 837. http://dx.doi.org/10.1007/s00445-014-0837-3.

Francis, P.W., 1983. Giant volcanic calderas. Sci. Am. 248, 60-70. http://dx.doi.org/10. 1038/scientificamerican0683-60.

Fridrich, C.J, Smith, R.P. Dewitt, E, Mdkee, E.H., 1991. Structural, eruptive, and intrusive evolution of the Grizzly Peak caldera, Sawatch Range, Colorado. Geol. Soc. Am. Bull. 103, 1160-1177. http://dx.doi.org/10.1130/0016-7606(1991)103.

Gauthier, P.-J., 2001. Géochimie des fluides et des gaz émis par le système volcanohydrothermal du volcan Yasur, Ile de Tanna, République du Vanuatu. Unpublished report, Laboratoire Magmas et Volcans, 55 pp.

Gauthier, P.-J., Goff, F, Love, S., Counce, D., 2001. Geochemical surveillance of fluid and gas discharges at Yasur volcanic complex, Tanna island, Vanuatu. EUG XI General Assembly, Strasbourg, France (pp. Abstract H62024).

GEM-Systems-Inc, 2008. GSM-19 Instruction Manual. Markham (Canada) (148 pp.).

Hochstein, M.P, Soengkono, S., 1997. Magnetic anomalies associated with high temperature reservoirs in the Taupo volcanic zone (New Zealand). Geothermics 26 (1), 1-24.

Houghton, B.F., Wilson, CJ.N., 1989. A vesicularity index for pyroclastic deposits. Bull. Volcanol. 51, 451-462. http://dxdoi.org/10.1007/BF01078811.

Hurwitz, S, Christiansen, L.B., Hsieh, P.A., 2007. Hydrothermal fluid flow and deformation in large calderas: inferences from numerical simulations. J. Geophys. Res. 112, 1-16. http://dx.doi.org/10.1029/2006JB004689.

Kane, M.F., Mabey, D.R., Brave, R.-L, 1976. A gravity and magnetic investigation of the Long Valley Caldera, Mono County, California. J. Geophys. Res. 81 (5), 754-762.

Kauahikaua, J., 1993. Geophysical characteristics of the hydrothermal systems of Kilauea volcano, Hawaii. Geothermics 22, 271-299.

Kennedy, B., Wilcock, J., Stix, J., 2012. Caldera resurgence during magma replenishment and rejuvenation at Valles and Lake City calderas. Bull. Volcanol. 74 (8), 1833-1847.

Kremers, S., Wassermann, J., Meier, K., Pelties, C, van Driel, M, Vasseur, J., Hort, M, 2013. Inverting the source mechanism of Strombolian explosions at Mt. Yasur, Vanuatu, using a multi-parameter dataset. J. Volcanol. Geotherm. Res. 262, 104-122. http:// dx.doi.org/10.1016/j.jvolgeores.2013.06.007.

Lardy, M., Tabbagh, A., 1999. Measuring and interpreting heat fluxes from shallow volcanic bodies using vertical temperature profiles: a preliminary test. Bull. Volcanol. 60 (6), 441-447.

Lénat, J.-F., 1995. Geoelectrical methods in volcano monitoring. In: McGuire, B., Kilburn, C.R.J., Murray, J. (Eds.), Monitoring Active Volcanoes: Strategies, Procedures and Techniques. UCL Press, London, pp. 248-274.

Lipman, P.W., 1984. The roots of ash flow calderas in Western North America: windows into the tops of granitic batholiths. J. Geophys. Res. 89, 8801-8841.

Loke, M.H., 2014. Electrical imaging surveys for environmental and engineering studies. A Practical Guide to 2-D and 3-D Surveys (www.geotomosoft.com).

Loke, M.H., Barker, R.D., 1996. Rapid least-squares inversion of apparent resistivity pseudosections using a quasi-Newton method. Geophys. Prospect. 44 (1), 131-152.

Louat, R., Baldassari, C, 1989. Chronologie des séismes et des tsunamis ressentis dans la région Vanuatu Nouvelle Calédonie (1729-1989). Rapp. Sci. Tech. I'IRD-. Terre Geophys. 1 (52 pp.). 
Mahood, G., Hildreth, W., 1986. Geology of the peralkaline volcano at Pantelleria, Strait of Sicily. Bull. Volcanol. 48, 143-172.

Malahoff, A., 1970. Gravity and Magnetic Studies of the New Hebrides Iland Arc. New Hebrides Condominium Geological Survey (67 pp.).

Marchetti, E, Ripepe, M, Delle Donne, D., Genco, R, Finizola, A., Garaebiti, E., 2013. Blast waves from violent explosive activity at Yasur Volcano, Vanuatu. Geophys. Res. Lett. 40, 5838-5843. http://dx.doi.org/10.1002/2013GL057900.

Marsh, B.D., 1984. On the mechanics of caldera resurgence. J. Geophys. Res. 89, 8245-8251. http://dx.doi.org/10.1029/JB089iB10p08245.

Masturyono, McCaffrey, R., Wark, DA., Roecker, S.W., Fauzi, Ibrahim, G., Sukhyar, 2001. Distribution of magma beneath the Toba caldera complex, north Sumatra, Indonesia, constrained by three-dimensional $\mathrm{P}$ wave velocities, seismicity, and gravity data. Geochem. Geophys. Geosyst. 2. http://dx.doi.org/10.1029/2000GC000096.

Merle, O, Brothelande, E., Lénat, J.-F., Bachèlery, P., Garabéiti, E, 2013. A structural outline of the Yenkahe volcanic resurgent dome (Tanna Island, Vanuatu Arc, South Pacific). J. Volcanol. Geotherm. Res. 268, 64-72. http://dx.doi.org/10.1016/j.jvolgeores.2013. 10.009 .

Metrich, N., Allard, P., Aiuppa, A., Bani, P., Bertagnini, A., Shinohara, H., Parello, F., Di Muro, A., Garaebiti, E., Belhadj, O., Massare, D., 2011. Magma and volatile supply to postcollapse volcanism and block resurgence in Siwi Caldera (Tanna Island, Vanuatu Arc). J. Petrol. 52 (6), 1077-1105.

Nabyl, A., Dorel, J, Lardy, M., 1997. A comparative study of low-frequency seismic signals recorded at Stromboli volcano, Italy, and at Yasur volcano, Vanuatu. N. Z J. Geol. Geophys. 40 (4), 549-558.

Nairn, I.A., Scott, B.J, Giggenbach, W.F., 1988. Yasur volcanic investigations, Vanuatu September 1988. N. Z. Geol. Surv. Rep. G136, 1-74.

Neef, G., Zhao, J.X, Collerson, K.D, Zhang, F.S, 2003. Late Quaternary uplift and subsidence of the west coast of Tanna, south Vanuatu, southwest Pacific: U-Th ages of raised coral reefs in the Median Sedimentary Basin. Aust. J. Earth Sci. 50 (1), 39-48.

Newhall, C.G., Dzurisin, D., 1988. Historical unrest at large calderas of the world. US. Geol. Surv. Bull. 1855, 1108.

Oppenheimer, C, Bani, P., Calkins, J.A., Burton, M.R., Sawyer, G.M., 2006. Rapid FIIR sensing of volcanic gases released by Strombolian explosions at Yasur volcano, Vanuatu. Appl. Phys. B Lasers Opt. 85 (2-3), 453-460.

Palmason, G., 1975. Geophysical methods in geothermal exploration. 2nd UN Symposium on the Development and Use of Geothermal Resources. U.S. Government Printing Office, Washington, D. C, pp. 1175-1184.

Paton, M.W., Paton, J, 1894. Letters and Sketches from the New Hebrides. London Hodder and Stoughton (https://archive.org/details/letterssketchesfo0patorich).

Pelletier, B., Calmant, S., Pillet, R., 1998. Current tectonic of the Tonga-New Hebrides region. Earth and Planetary Science Letters. Earth Planet. Sa. Lett. 164, 263-276.

Peltier, A., Finizola, A., Douillet, G., Brothelande, E., Garaebiti, E., 2012. Structure of an active volcano associated with a resurgent block inferred from thermal mapping: the Yasur-Yenkahe complex (Vanuatu). J. Volcanol. Geotherm. 243-244, 59-68.
Perrier, L, Métaxian, J.P., Battaglia, J, Garaebiti, E.,2012. Estimation of the near-surface velocity structure of the Yasur-Yenkahe volcanic complex, Vanuatu. J. Volcanol. Geotherm. Res. 227, 50-60.

Phillips, E.H., Goff, F., Kyle, P.R., McIntosh, W.C, Dunbar, N.W., Gardner, J.N., 2007. The Ar40/Ar-39 age constraints on the duration of resurgence at the Valles caldera, New Mexico. J. Geophys. Res. 112 (B8).

Rapolla, A. Fedi, M., Fiume, M.G., 1989. Crustal structure of the Ischia-Phlegrean geothermal fields, near Naples, Italy, from gravity and aeromagnetic data. Geophys. J. Oxf. 97 (3), 409-419.

Robin, C., Eissen, J.P., Monzier, M., 1994. Ignimbrites of Basaltic Andesite and Andesite Compositions from Tanna, New-Hebrides Arc. Bull. Volcanol. 56 (1), 10-22.

Rosenberg, P.E., 1988. Aluminum fluoride hydrates, yolcanogenic salts from Mount Erebus, Antarctica. Am. Mineral. 73, 855-860.

Sacchi, M., Pepe, F., Corradino, M., Insinga, D.D., Molissoa, L.F.C., 2014. The Neapolitan Yellow Tuff caldera offshore the Campi Flegrei: stratal architecture and kinematic reconstruction during the last $15 \mathrm{ky}$. Mar. Geol. 354, 15-33.

Smith, R.L., Bailey, R.A., 1968. Resurgent cauldrons. Geol. Soc. Am. Mem. 116, 613-662 http://dx.doi.org/10.1130/MEM116.

Steven, T.A., Lipman, P.W., 1976. Calderas of the San Juan Volcanic Field, Southwestern Colorado. USGS Prof. Pap. 958, 1-35.

Swanson, E.R., McDowell, F.W., 1985. Geology and geochronology of the Tomochic caldera, Chihuahua, Mexico. Geol. Soc. Am. Bull. 96, 1477-1482.

Tibaldi, A., Vezzoli, L, 1998. The space problem of caldera resurgence: an example from Ischia Island, Italy. Geol. Rundsch. 87, 53-66. http://dx.doi.org/10.1007/ s005310050189.

Tibaldi, A., Vezzoli, L, 2004. A new type of volcano flank failure: the resurgent caldera sector collapse, Ischia, Italy. Geophys. Res. Lett. 31. http://dx.doi.org/10.1029/ 2004 GL020419.

Troise, C., De Natale, G., Pingue, F., Obrizzo, F., De Martino, P., Tammaro, U., Boschi, E., 2007. Renewed ground uplift at Campi Flegrei caldera (Italy): new insight on magmatic processes and forecast. Geophys. Res. Lett. 34. http://dx.doi.org/10.1029/ 2006GL028545.

Witham, C.S., Oppenheimer, C, Horwell, C.J., 2005. Volcanic ash-leachates: a review and recommendations for sampling methods. J. Volcanol. Geotherm. Res. 141, 299-326.

Yoshida, T, 1984. Tertiary Ishizuchi cauldron, southwestern Japan arc: formation by ring fracture subsidence. J. Geophys. Res, Solid Earth 89, 8502-8510.

Zielinski, C, 2012. Ecouter les volcans pour mieux les comprendre: volcans de la zone de subduction du Vanuatu University Thesis Université Denis Diderot, Institut de Physique du Globe, Paris. 